\title{
The effect of dry and wet deposition of condensable vapors on secondary organic aerosols concentrations over the continental US
}

\author{
C. Knote ${ }^{1, *}$, A. Hodzic ${ }^{1}$, and J. L. Jimenez ${ }^{2}$ \\ ${ }^{1}$ Atmospheric Chemistry Division, NCAR, Boulder, CO, USA \\ ${ }^{2}$ Department of Chemistry and Biochemistry, University of Colorado at Boulder, CO, USA \\ *now at: Meteorologisches Institut München, Ludwig-Maximilians-Universität, Munich Germany
}

Correspondence to: A. Hodzic (alma@ucar.edu)

Received: 10 May 2014 - Published in Atmos. Chem. Phys. Discuss.: 26 May 2014

Revised: 28 October 2014 - Accepted: 18 November 2014 - Published: 6 January 2015

\begin{abstract}
The effect of dry and wet deposition of semivolatile organic compounds (SVOCs) in the gas phase on the concentrations of secondary organic aerosol (SOA) is reassessed using recently derived water solubility information. The water solubility of SVOCs was implemented as a function of their volatility distribution within the WRFChem regional chemistry transport model, and simulations were carried out over the continental United States for the year 2010. Results show that including dry and wet removal of gas-phase SVOCs reduces annual average surface concentrations of anthropogenic and biogenic SOA by 48 and $63 \%$ respectively over the continental US. Dry deposition of gasphase SVOCs is found to be more effective than wet deposition in reducing SOA concentrations $(-40$ vs. $-8 \%$ for anthropogenics, and -52 vs. $-11 \%$ for biogenics). Reductions for biogenic SOA are found to be higher due to the higher water solubility of biogenic SVOCs. The majority of the total mass of SVOC + SOA is actually deposited via the gas phase (61\% for anthropogenics and $76 \%$ for biogenics). Results are sensitive to assumptions made in the dry deposition scheme, but gas-phase deposition of SVOCs remains crucial even under conservative estimates. Considering reactivity of gas-phase SVOCs in the dry deposition scheme was found to be negligible. Further sensitivity studies where we reduce the volatility of organic matter show that consideration of gas-phase SVOC removal still reduces average SOA concentrations by $31 \%$ on average. We consider this a lower bound for the effect of gas-phase SVOC removal on SOA concentrations. A saturation effect is observed for Henry's law constants above $10^{8} \mathrm{M} \mathrm{atm}^{-1}$, suggesting an upper bound of reductions in surface level SOA concentra-
\end{abstract}

tions by $60 \%$ through removal of gas-phase SVOCs. Other models that do not consider dry and wet removal of gasphase SVOCs would hence overestimate SOA concentrations by roughly $50 \%$. Assumptions about the water solubility of SVOCs made in some current modeling systems $\left(H^{*}=H^{*}\left(\mathrm{CH}_{3} \mathrm{COOH}\right) ; H^{*}=10^{5} \mathrm{M} \mathrm{atm}^{-1} ; H^{*}=H^{*}\left(\mathrm{HNO}_{3}\right)\right)$ still lead to an overestimation of $35 \% / 25 \% / 10 \%$ compared to our best estimate.

\section{Introduction}

Organic compounds represent a major, often dominant mass fraction of ambient aerosol (e.g., Murphy et al., 2006; Jimenez et al., 2009). Most of this mass results from the multigenerational oxidation of hydrocarbons forming products with lower volatility (Odum et al., 1996; Jimenez et al., 2009). The resulting oxygenated semivolatile organic compounds (SVOCs) equilibrate between the gas and the particle phases according to their saturation vapor pressure $C^{*}$ ( $\mu \mathrm{g} \mathrm{m}^{-3}$, Pankow, 1994). Under ambient conditions in the troposphere, SVOCs with a $C^{*}$ below $0.1 \mu \mathrm{g} \mathrm{m}^{-3}$ are predominantly found in the particle phase, while products with saturation vapor pressure $C^{*}$ between 0.1 and $10^{3} \mu \mathrm{g} \mathrm{m}^{-3}$, are distributed between the gas and the particle phase with significant mass fractions in both phases. Aerosol volatility measurements during the MILAGRO campaign in Mexico City and similar observations for the Los Angeles area (Cappa and Jimenez, 2010) estimated that for organic material with $C^{*} \leq 10^{3} \mathrm{\mu g} \mathrm{m}^{-3}$ the total amount in the gas phase is between 0.7 to 2.4 times that of the mass in the parti- 
cle phase. Recent findings from explicit oxidation chemistry modeling (Hodzic et al., 2013, 2014a) with the Generator of Explicit Chemistry and Kinetics of Organics in the Atmosphere (GECKO-A Aumont et al., 2005) together with structure-activity estimation of solubility (Raventos-Duran et al., 2010) suggests that many SVOCs are highly water soluble, with Henry's law constants $H^{*}$ between $10^{5}$ and $10^{10} \mathrm{Matm}^{-1}$. This makes them very susceptible to removal processes in the atmosphere (wet deposition and dry deposition to wet surfaces/vegetation). Given that gas and particle phases are in equilibrium, this also implies that removal of gas-phase SVOCs could be an important indirect sink of secondary organic aerosol (SOA) mass.

Currently, the removal of organic aerosols in 3-D models relies for the main part on wet deposition of aerosols (Tsigaridis et al., 2014) and the model's ability to accurately predict clouds and precipitation. Dry deposition of aerosols is a small contributor to this removal. Deposition of gas-phase SVOCs in current modeling systems is largely unconstrained and, if considered at all, typically scaled to the deposition of $\mathrm{HNO}_{3}, \mathrm{CH}_{3} \mathrm{COOH}$, or other reference compounds with known solubility. Bessagnet et al. (2010) investigated the effect of dry deposition of gas-phase SVOCs on SOA concentrations over Europe. In their simulations they used Henry's law constants from different reference compounds (with $H^{*}$ ranging from $10^{5}$ to $10^{16} \mathrm{M} \mathrm{atm}^{-1}$ ) and found that SOA concentrations are reduced by 20 to $30 \%$ when including dry deposition of gas-phase SVOCs, mostly due to the removal of biogenic SVOCs. Pye and Seinfeld (2010) applied the global GEOS-chem model to look at the SOA formation from low volatile compounds. For SVOCs, they distinguished between freshly emitted ones with a very low Henry's law constant $\left(<10 \mathrm{M} \mathrm{atm}^{-1}\right)$ and oxidation products that are treated using a Henry's law constant of $10^{5} \mathrm{M} \mathrm{atm}^{-1}$. They found that a considerable fraction is removed through the gas phase, and that wet deposition dominates the removal pathways. In a sensitivity study they lowered the Henry's law constants for, SVOCs and showed that the global organic aerosol (OA) budget is sensitive to this parameter, but they concluded that this does not decrease the model bias against observations. Ahmadov et al. (2012) implemented a volatility basis set (VBS) model into WRF-Chem and found that SOA concentrations are very sensitive to the assumptions made on dry deposition of gas-phase SVOCs. They did not include wet deposition, and tentatively suggested to dry deposit SVOCs in the gas phase 0.25 to 0.5 times the rate of $\mathrm{HNO}_{3}$ to optimize the agreement with observations. These studies show that treatment of gas-phase SVOC removal can significantly affect our ability to accurately predict SOA concentrations. Recently, Hodzic et al. (2014a) have provided a parameterization of the water solubility of SVOCs based on explicit oxidation chemistry modeling combined with estimation of Henry's law constants that is constrained from experimental data. Their results show that SVOC mixtures typically created through oxidation in the atmosphere are highly water soluble, 2-3 orders of magnitude higher than assumed in Pye and Seinfeld (2010). No previous study investigated the combined effect of dry as well as wet deposition of SVOCs in the gas phase with such high values for water solubility.

In this work we have integrated the new findings of Hodzic et al. (2014a) regarding the solubility of SVOCs into a stateof-the-art online modeling system (WRF-Chem) and perform a detailed assessment of the effects of the gas-phase SVOC wet and dry deposition on predicted SOA concentrations over North America. We implemented a volatility basis set (VBS) scheme with 5 volatility bins in our configuration of WRF-Chem based the work of Lane et al. (2008b) and Ahmadov et al. (2012) to consider the formation of compounds with lower volatility and their partitioning the between gas and aerosol phases. The dry and wet deposition schemes in WRF-Chem were extended to consider removal of gas-phase SVOCs based on their estimated Henry's law constants for each volatility bin. Simulations were performed for the full year of 2010 to understand the impact of these removal processes under very different ambient conditions, and test their robustness within the model parameter space.

In Sect. 2 we present the modeling approach. Section 3 deals with the evaluation of model performance in terms of precipitation and removal of inorganic substances. In Sect. 4, we address the effects of dry/wet removal of gasphase SVOCs on SOA concentrations before we evaluate a number of uncertainties in our simulations in Section 5.

\section{Modeling}

WRF-Chem (Grell et al., 2005) in version 3.5 is used for all simulations. Meteorological processes and their parameterizations chosen for our simulations are summarized in Table 1 .

The MOZART-4 gas-phase mechanism (Emmons et al., 2010) with more explicit treatment of aromatic compounds (Knote et al., 2014) and monoterpenes (Hodzic et al., 2014b) is used together with the MOSAIC aerosol module (Zaveri et al., 2008) with 4 size bins.

\subsection{The volatility basis set}

MOSAIC has been extended by a volatility basis set parameterization to describe SOA formation based on the work of Lane et al. (2008a, b) and (Ahmadov et al., 2012). In Fig. 1 we present a schematic overview of the new module. Five volatility bins are considered (saturation concentrations $C^{*}$ of $10^{-4}, 1,10,100$ and $1000 \mu \mathrm{g} \mathrm{m}^{-3}$ at $298 \mathrm{~K}$ ) for both anthropogenic and biogenic precursors (see Table S1 in the Supplement for mapping SAPRC99 species to MOZART). The lowest volatility bin $\left(C^{*}\right.$ of $\left.10^{-4} \mu \mathrm{g} \mathrm{m}^{-3}\right)$ has been added to avoid an unrealistically volatile mixture after substantial aging. We consider different SOA yields for low and high $\mathrm{NO}_{\mathrm{x}}$ conditions, and the branching ratio $\mathrm{B}$ to determine the 
Table 1. Chosen parameterizations for selected physical processes in WRF.

\begin{tabular}{ll}
\hline Process & Parameterization \\
\hline Radiation & RRTMG short- and longwave \\
Cloud microphysics & Morrison double-moment scheme \\
Land surface & Noah Land Surface Model \\
Urban surface & Urban Canopy Model \\
Planetary boundary layer & Mellor-Yamada Nakanishi and Niino 2.5 \\
Cumulus parameterization & Grell 3-D ensemble \\
\hline
\end{tabular}

respective contributions is calculated according to Lane et al. (2008a) as

$\beta=k_{\left(\mathrm{RO}_{2}+\mathrm{NO}\right)}[\mathrm{NO}] /\left(k_{\left(\mathrm{RO}_{2}+\mathrm{NO}\right)}[\mathrm{NO}]+k_{\left(\mathrm{RO}_{2}+\mathrm{HO}_{2}\right)}\left[\mathrm{HO}_{2}\right]\right)$

with $k_{\left(\mathrm{RO}_{2}+\mathrm{NO}\right)}$ and $k_{\left(\mathrm{RO}_{2}+\mathrm{HO}_{2}\right)}$ as the reaction rate constants for the reaction of an organic peroxy radical $\left(\mathrm{RO}_{2}\right)$ with $\mathrm{NO}$ vs. its reaction with $\mathrm{HO}_{2}$, respectively. $\mathrm{OH}$ and $\mathrm{O}_{3}$ act as oxidizing agents. To reduce the computational burden we sum up all mass formed from anthropogenic and biogenic precursors, respectively, and only keep track of total anthropogenic and total biogenic SVOC/SOA mass (called aSVOC/bSVOC and aSOA/bSOA in the following). Pseudo-ideal partitioning theory based on Pankow (1994) is used to estimate gasaerosol partitioning as implemented in MOSAIC by Shrivastava et al. (2011). Values for the enthalpy of vaporization $(\Delta H)$ for each bin have been derived using the semiempirical parameterization of Epstein et al. (2009) leading to values between 100 and $140 \mathrm{~kJ} \mathrm{~mol}^{-1}$ for the bins with $C^{*}$ of $1,10,100$, and $1000 \mu \mathrm{g} \mathrm{m}^{-3}$ (see Fig. 1 for exact values). The lowest volatility bin uses a $\Delta H$ of $40 \mathrm{~kJ} \mathrm{~mol}^{-1}$. The "aging" of condensable vapors through $\mathrm{OH}$ oxidation (mass transfer into the next lower volatility bin) is done with a fixed rate of $1.0 \times 10^{-11} \mathrm{~cm}^{3} \mathrm{molec}^{-1} \mathrm{~s}^{-1}$ (Murphy and Pandis, 2009 ), and a $7.5 \%$ mass increase due to the addition of oxygen atoms (e.g., Ahmadov et al., 2012). Secondary aerosol mass formed is assumed to have a density of $1.5 \mathrm{~g} \mathrm{~m}^{-3}$ (Lane et al., 2008a) and a molecular weight of $250 \mathrm{~g} \mathrm{~mol}^{-1}$. Direct emissions of organic particulates (primary organic aerosols, POA) are included as inert contribution to aerosol mass without consideration of evaporation and re-condensation. Direct emissions of semi-/intermediate volatility organic compounds (SVOC/IVOC) are not included.

\subsection{Dry and wet deposition of gases and aerosols}

Washout of gases and aerosols by convective precipitation is considered using the scheme included in WRF-Chem (based on Grell and Dévényi, 2002) which we modified to use Henry's law constants in gas-droplet partitioning. Gridscale precipitation removes aerosols through the scheme implemented in MOSAIC (Easter et al., 2004; Chapman et al., 2009), while washout of trace gases is performed as described in (Neu and Prather, 2012). The Neu and Prather (2012) scheme also employs an equilibrium approach based

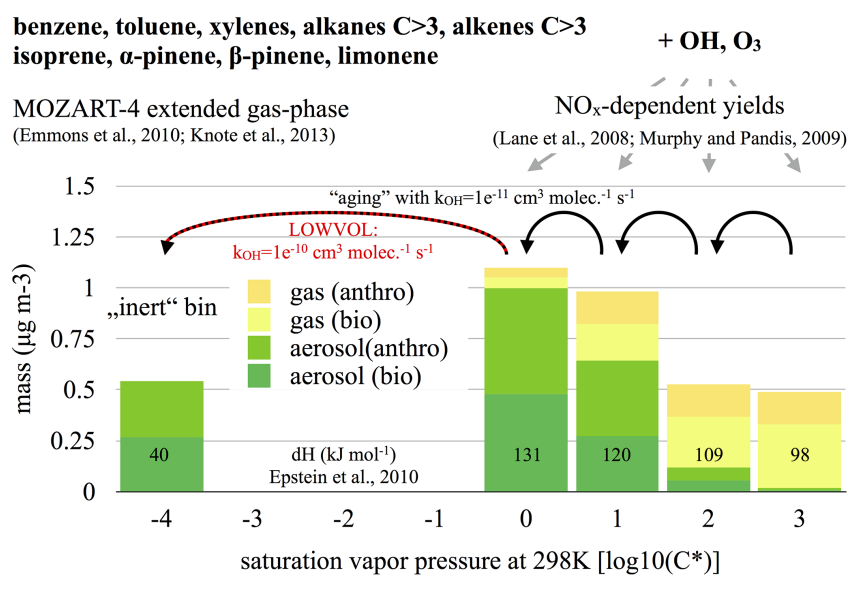

Figure 1. Schematic overview of the volatility basis set as implemented in WRF-Chem. SOA/SVOC values are surface level concentrations from the REF simulation averaged over the full year 2010 and the CONUS domain (land points only).

on Henry's law constants to consider transfer into cloud droplets and subsequent conversion into rain droplets, as well as collection of gases by falling rain droplets. Both, washout through grid-scale and convective precipitation considers the same set of gas species with an identical set of Henry's law constants. Dry deposition of gases is parameterized in WRFChem based on Wesely (1989), modeling deposition as a series of resistors consisting of an atmospheric, a laminar sublayer, and a bulk surface resistance. The latter is a function of the Henry's law constant of a gas through its use in the calculation of the mesophyll and leaf cuticular resistance of vegetation. The lower canopy (representing structures, buildings, etc.) and ground resistances scale with the Henry's law constant as well, irrespective of whether the surface is wet or not. A reactivity factor $f_{0}$ (ranging from $f_{0}=0$ for non-reactive species to $f_{0}=1$ for species as reactive as $\mathrm{O}_{3}$ ) is used in this scheme to consider oxidation of biological substances within plants once a species partitions into this volume. This is set to 0.0 for SVOCs.

Henry's law constants $\left(H^{*}, \mathrm{Matm}^{-1}\right)$ used in this study for semi-volatile organic compounds were provided as a function of volatility by Hodzic et al. (2014a). They applied an explicit chemical mechanism (GECKO-A, Aumont et al., 2005) to generate the multi-generational oxidation products of individual SOA precursors and calculate the associated $H^{*}$ values using structure activity relationships (RaventosDuran et al., 2010). Values of $H^{*}$ were taken at the maximum of the SOA formation from each individual precursor, which is typically after 1-3 days of chemical processing depending on the precursor, and provided as a function of the volatility (VBS bins). In each volatility bin, a mass-weighted $H^{*}$ was calculated (see Table 1 in Hodzic et al., 2014a). Using those values, we calculated in this study an averaged $H^{*}$ for both biogenic and anthropogenic precursor species (Table 2). Dry 
and/or wet deposition of these volatile compounds is then considered by adding these species to the respective modules in WRF-Chem described above.

\subsection{Model setup}

Simulations were set up to cover the continental US at $36 \mathrm{~km}$ horizontal resolution and 33 levels up to $50 \mathrm{hPa}$. Meteorological parameters are initialized and forced at the boundaries by 6-hourly analyses (interlaced with 3-hourly forecasts) of the Global Forecasting System (GFS) of the National Center for Environmental Prediction (National Centers for Environmental Prediction/National Weather Service/NOAA/US Department of Commerce, 2010). Initial and boundary conditions for chemistry are provided by simulations of the IFS-MOZART global chemistry transport model (Stein et al., 2012) conducted within the MACC (Monitoring Atmospheric Composition and Climate) project. Emissions of trace gases and aerosols are those provided in phase 2 of the Air Quality Model Evaluation International Initiative model intercomparison (AQMEII, Alapaty et al., 2012). For the United States, the 2008 National Emission Inventory (NEI) (version 2, released April 10, 2012) was used (http:// www.epa.gov/ttn/chief/net/2008inventory.html). Updates for the following sectors were applied to reflect changes in emissions between 2008 and 2010: on/off road transport, wildfires and prescribed fires, and continuous-emission-monitoringequipped (CEM-equipped) point sources. Preparation of the emission data is described in detail in Pouliot et al. (2014). Emission conversion tables for the MOZART/MOSAIC setup used in this work are given in Tables S2/S3.

The simulations are split into $48 \mathrm{~h}$ long chunks of free running meteorology (only forced at the boundaries) without nudging. Each of these runs is preceded by a $6 \mathrm{~h}$ meteorology-only spin-up which is started from GFS analyses and nudged to this data set above the planetary boundary layer. Concentration fields for trace gases and aerosol quantities resulting from the previous run are then used to initialize the following free run. Thereby, meteorology is restarted from analyses every $48 \mathrm{~h}$, while chemistry is continuous over the whole period. All simulations have been conducted on NCAR's Yellowstone computing system (Computational and Information Systems Laboratory, 2012). The $\mathrm{R}$ language (http://www.r-project.org) was used for postprocessing and analysis.

Table 3 lists all simulations conducted. In a first simulation (NODEP), we ignore both dry and wet deposition of SVOCs. In three further simulations, we consider dry, wet, and dry + wet deposition of SVOCs (called DRY, WET and REF, respectively) employing Henry's law values calculated by Hodzic et al. (2014a). The simulation with dry and wet deposition of SVOCs according to Hodzic et al. (2014a) is our best estimate and hence called REF. All these simulations were carried out for the full year of 2010 with an additional 1 week of spin-up for chemistry (not used in the analysis).
Table 2. Henry's law constants $H^{*}\left(\mathrm{M} \mathrm{atm}^{-1}\right)$ for different volatility bins $\left(C^{*}\right.$ in $\mu \mathrm{g} \mathrm{m}^{-3}$, at $\left.298 \mathrm{~K}\right)$ as derived in Hodzic et al. (2014a). Shown are averaged values used for anthropogenic and biogenic semi-volatile mixtures. All water solubilities are used with a temperature dependence of $6014\left(-\mathrm{d} \ln \left(H^{*}\right) / \mathrm{d}(1 / T)\right)$.

\begin{tabular}{lrrrr}
\hline & 1 & 10 & 100 & 1000 \\
\hline anthropogenic & $1.1 \times 10^{8}$ & $1.8 \times 10^{7}$ & $3.2 \times 10^{6}$ & $5.5 \times 10^{5}$ \\
biogenic & $5.3 \times 10^{9}$ & $7.0 \times 10^{8}$ & $9.3 \times 10^{7}$ & $1.2 \times 10^{7}$ \\
\hline
\end{tabular}

A number of sensitivity studies were conducted to understand the sensitivity of the predictions to uncertainties in the process parameterizations. In LOWVOL and FAST_AGING, we vary the SOA formation mechanism. In LOWVOL we decrease the overall volatility of the SOA formed by increasing the rate of aging from the volatility bin at $C^{*}=$ $1 \mu \mathrm{g} \mathrm{m}^{-3}$ to the one with $C^{*}=10^{-4} \mu \mathrm{g} \mathrm{m}^{-3}$ by a factor of 10 , thereby moving aged SOA to a bin with negligible partitioning into the gas phase and hence leaving less SVOC that would be susceptible to the newly included removal processes. In FAST_AGING, we increase the aging rate constants for all volatility bins to $4.0 \times 10^{-11} \mathrm{~cm}^{3} \mathrm{molec}^{-1} \mathrm{~s}^{-1}$, thereby matching assumptions about the rate of aging used in previous modeling studies (e.g., Athanasopoulou et al., 2013), and again decreasing the amount of SVOC available for removal. Five additional simulations were conducted to determine the model sensitivity to assumptions about the Henry's law constants of SVOCs and identify a possible saturation effect at very high $H^{*}$ values in the dry deposition scheme. The Wesely (1989) scheme used represents dry deposition as a series of resistances, with only the land surface/canopy resistance being affected by changes in $H^{*}$. At very high $H^{*}$, this resistance should become negligible and dry deposition would be governed by the remaining resistances. In H_1E5, H_1E8 and H_1E10, we employ Henry's law constants for SVOCs of $10^{5}, 10^{8}$, and $10^{10} \mathrm{Matm}^{-1}$, respectively, in both dry and wet deposition. The fourth simulation (H_HNO3) uses the Henry's law constant of $\mathrm{HNO}_{3}$ for SVOCs. The solubility of $\mathrm{HNO}_{3}$ (or a fraction of it) is often used in atmospheric modeling to treat compounds with unknown properties, but which are assumed to be very soluble. The fifth simulation (H_ACETIC) employs the Henry's law constant of acetic acid $\left(\mathrm{CH}_{3} \mathrm{COOH}\right)$, as this is very similar to the values currently used in the Community Multi-scale Air Quality model (CMAQ, https://www.cmascenter.org/cmaq/). In the VEGFRA simulation, we assess uncertainties in the description of dry deposition by scaling dry deposition velocities with the vegetated fraction of each grid cell. Finally, two further simulations (F_0.1 and F_1.0) were made to investigate the effect of the reactivity factor $f_{0}$ on predictions. Which SVOCs should be considered "reactive" is so far poorly constrained, but Karl et al. (2010) suggested that assuming $f_{0}=0.1$ or 0.0 , as it is typically done for 
Table 3. Simulations conducted. DD/WD denotes if dry/wet deposition of SVOCs is considered, and $H^{*}$ refers to the Henry's law constants used for SVOCs. xVEGFRA states whether dry deposition velocities are scaled by the vegetation fraction of each grid cell (see text). $\mathrm{kOH}$ denotes the aging rate constant $(\mathrm{SVOC}+\mathrm{OH})$ and $f_{0}$ to the reactivity parameter in the Wesely (1989) dry deposition scheme. $\mathrm{kOH}$ is reported as $\mathrm{cm}^{3} \mathrm{molec}^{-1} \mathrm{~s}^{-1}, H^{*}$ as $\mathrm{Matm}^{-1}$, the temperature dependence as $-\mathrm{d} \ln \left(H^{*}\right) / \mathrm{d}(1 / T)$. Parameters varied compared to the REF simulation are shown in bold font.

\begin{tabular}{|c|c|c|c|c|c|c|}
\hline case name & DD & WD & $H^{*}(T$ dependence $)$ & xVEGFRA & $f_{0}$ & $k \mathrm{OH}$ \\
\hline REF & $\mathrm{x}$ & $\mathrm{x}$ & Hodzic et al. (2014a) & & 0.0 & $1.0 \times 10^{-11}$ \\
\hline DRY & $\mathrm{x}$ & & Hodzic et al. (2014a) & & 0.0 & $1.0 \times 10^{-11}$ \\
\hline WET & & $\mathrm{x}$ & Hodzic et al. (2014a) & & 0.0 & $1.0 \times 10^{-11}$ \\
\hline NODEP & & & no SVOC deposition & & 0.0 & $1.0 \times 10^{-11}$ \\
\hline \multicolumn{7}{|c|}{ SOA volatility } \\
\hline LOWVOL & $\mathrm{x}$ & $\mathrm{x}$ & Hodzic et al. (2014a) & & 0.0 & $1 \times 10^{-11}, 1 \times 10^{-10}$ for $C^{*}=1.0$ \\
\hline LOWVOL_NODEP & & & no SVOC deposition & & 0.0 & $1 \times 10^{-11}, 1 \times 10^{-10}$ for $C^{*}=1.0$ \\
\hline FAST_AGING & $\mathrm{x}$ & $\mathrm{x}$ & Hodzic et al. (2014a) & & 0.0 & $4.0 \times 10^{-11}$ \\
\hline FAST_AGING_NODEP & & & no SVOC deposition & & 0.0 & $4.0 \times 10^{-11}$ \\
\hline \multicolumn{7}{|c|}{ SVOC solubility } \\
\hline H_ACETIC & $\mathrm{x}$ & $\mathrm{x}$ & $4.1 \times 10^{3}(6300)$ & & 0.0 & $1.0 \times 10^{-11}$ \\
\hline H_HNO3 & $\mathrm{x}$ & $\mathrm{x}$ & $2.6 \times 10^{6}(8700)$ & & 0.0 & $1.0 \times 10^{-11}$ \\
\hline H_1E5 & $\mathrm{x}$ & $\mathrm{x}$ & $1.0 \times 10^{5}(0)$ & & 0.0 & $1.0 \times 10^{-11}$ \\
\hline H_1E8 & $\mathrm{x}$ & $\mathrm{x}$ & $1.0 \times 10^{8}(0)$ & & 0.0 & $1.0 \times 10^{-11}$ \\
\hline H_1E10 & $\mathrm{x}$ & $\mathrm{x}$ & $1.0 \times 10^{10}(0)$ & & 0.0 & $1.0 \times 10^{-11}$ \\
\hline \multicolumn{7}{|c|}{ dry deposition scheme } \\
\hline F_0.1 & $\mathrm{x}$ & $\mathrm{x}$ & Hodzic et al. (2014a) & & 0.1 & $1.0 \times 10^{-11}$ \\
\hline F_1.0 & $\mathrm{x}$ & $\mathrm{x}$ & Hodzic et al. (2014a) & & 1.0 & $1.0 \times 10^{-11}$ \\
\hline VEGFRA & $\mathrm{x}$ & $\mathrm{x}$ & Hodzic et al. (2014a) & $\mathbf{x}$ & 0.0 & $1.0 \times 10^{-11}$ \\
\hline VEGFRA_NODEP & & & no SVOC deposition & $\mathbf{x}$ & 0.0 & $1.0 \times 10^{-11}$ \\
\hline
\end{tabular}

NMVOCs (non-methane volatile organic compounds), might be too low for current modeling systems. We vary it here to $f_{0}=0.1$ (F_0.1) and $f_{0}=1.0\left(\mathrm{~F} \_1.0\right)$. All these sensitivity studies were conducted for the months of June, July, and August of 2010 only.

\section{Evaluation of predicted wet deposition}

An accurate description of the spatiotemporal variability of precipitation is a prerequisite for modeling (wet) deposition. In Fig. 2 we compare our simulations against a composite of rain gauge and radar observations from the $\mathrm{Na}-$ tional Weather Service River Forecast Centers (http://water. weather.gov/precip/download.php) which provides daily accumulated precipitation amounts. Apart from a tendency of the model to overestimate rainfall amounts in the rather dry regions of the western United States, the differences in the yearly accumulated precipitation are typically below $\pm 25 \%$.

Wet deposition measurements from the National Atmospheric Deposition Program (NADP, http://nadp.sws.uiuc. edu) are used to evaluate wet deposition of inorganic compounds $\left(\mathrm{SO}_{4}^{2-}, \mathrm{NO}_{3}^{-}, \mathrm{NH}_{4}^{+}\right)$. In Fig. 3 we compare monthly accumulated deposition of sulfate, nitrate and ammonium and find good agreement between model and measurements for sulfate (Pearson's correlation coefficient squared $R^{2}=$ 0.62 , normalized mean bias $\mathrm{NMB}=3 \%)$ and nitrate $\left(R^{2}=\right.$ $0.65, \mathrm{NMB}=7 \%$ ), while the amount of wet deposition of ammonium is underestimated but still has a good correlation with measurements $\left(R^{2}=0.69, \mathrm{NMB}=-38\right)$. This deficiency could be related to the lack of a bi-directional exchange model in WRF-Chem to describe the flux of $\mathrm{NH}_{3}$ at the surface (Nemitz et al., 2001; Bash et al., 2013). Measurements of water-soluble organics are not available, so we could not directly evaluate the performance of WRF-Chem. However, the model results of wet deposition of inorganic ions show that the underlying processes are reasonably modeled, lending credibility to the accuracy of the wet deposition of organic substances.

\section{Effect of SVOC deposition on SOA concentrations}

\subsection{Effect on SOA concentrations}

We first evaluate the differences in the average concentrations of SOA due to the removal of SVOCs. Dry deposi- 
Table 4. Contributions of dry and wet deposition through the gas / particle phase as well as resulting change in surface level SOA concentrations over the continental US in June, July, and August for selected sensitivity studies. Values in the two lowermost rows are percentual changes (\%), all other rows are accumulated deposited mass in $\mathrm{Gg}$.

\begin{tabular}{llcccccccc}
\hline & & \multicolumn{2}{c}{ REF } & \multicolumn{2}{c}{ LOWVOL } & \multicolumn{2}{c}{ FAST_AGING } & \multicolumn{2}{c}{ VEGFRA } \\
& & Anthro. & Biog. & Anthro. & Biog. & Anthro. & Biog. & Anthro. & Biog. \\
\hline \multirow{3}{*}{ Particle } & wet dep. & 21.9 & 19.4 & 15.5 & 13.7 & 32.7 & 31.8 & 24.2 & 24.5 \\
& dry dep. & 1.8 & 1.6 & 1.1 & 1.1 & 2.6 & 2.6 & 1.0 & 1.0 \\
& total & 23.7 & 21 & 16.6 & 14.8 & 35.3 & 34.4 & 25.2 & 25.5 \\
\hline \multirow{3}{*}{ Gas } & wet dep. & 12.0 & 17.4 & 6.5 & 9.6 & 6.3 & 10.8 & 12.7 & 20.3 \\
& dry dep. & 21.5 & 42.9 & 11.1 & 25.2 & 12.3 & 30.4 & 15.7 & 37.0 \\
& total & 33.5 & 60.3 & 17.6 & 34.8 & 18.6 & 41.2 & 28.4 & 57.3 \\
\hline Mass fraction lost by gas-phase dep. $(\%)$ & 59 & 74 & 51 & 70 & 35 & 54 & 53 & 69 \\
Avg. surface SOA conc. changes $(\%)$ & -41 & -56 & -32 & -48 & -23 & -39 & -31 & -45 \\
\hline
\end{tabular}

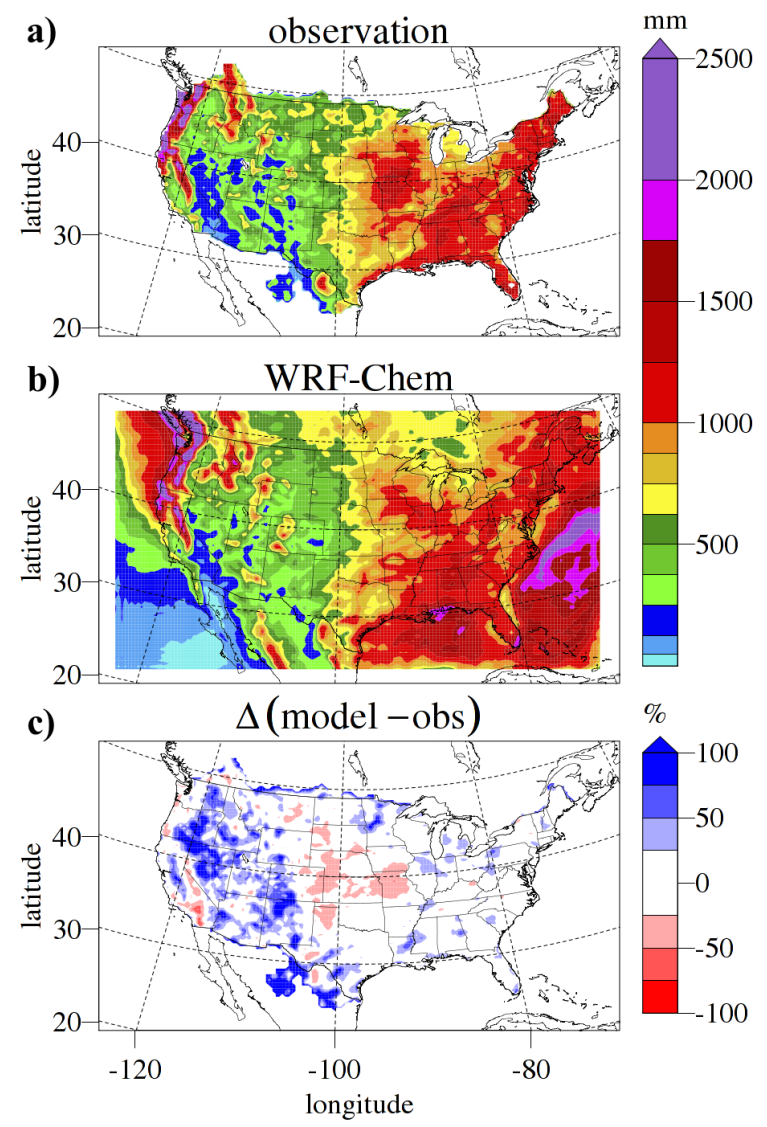

Figure 2. Year 2010 accumulated precipitation. (a) as observed by rain gauge/radar network. (b) WRF-Chem model results. (c) differences relative to observations $(\Delta($ model - obs $)=(\bmod -$ obs $) /$ obs $\times$ 100).

tion has a much stronger effect on SOA concentrations at the surface (top right map in Fig. 4) than does wet deposition (Fig. 4, bottom right map). As a yearly average over the continental US, dry deposition of SVOCs reduces SOA surface level concentrations by $46 \%$ (aSOA: $40 \%$, bSOA:
$52 \%$ ), whereas wet deposition leads to SOA concentrations at the surface that are lower by 10\% (aSOA: $8 \%$, bSOA: $11 \%$ ) vs. not considering this removal pathway (REF vs. NODEP case). We find very similar results when analyzing changes averaged over the planetary boundary layer instead of changes in the surface layer. SOA seems to be most sensitive to dry removal of SVOCs over the Pacific Northwest coast, the northern midwest (Montana, South/North Dakota) and parts of eastern Canada. Wet deposition is most effective around the Great Lakes area, and least effective over the Nevada/Utah/Arizona area as well as northeastern Texas. When looking at the average vertical profiles of SOA concentrations over land (Fig. 4, left panel), we find that the effects of these removal processes are visible throughout the vertical column. Dry deposition of SVOCs has the additional effect of removing a local maximum of SOA concentrations in the lowest model layers. When comparing the sum of the reductions due to only considering either dry (DRY) or wet (WET) deposition of SVOCs against the reductions in a simulation where we consider both processes (REF), we find that their effects are almost additive (not shown).

We evaluate the resulting total organic aerosol (OA) concentrations against measurements using measurements of the Interagency Monitoring of Protected Visual Environments network (IMPROVE, data hosted at http://www.epa.gov/ ttn/airs/airsaqs/detaildata/downloadaqsdata.htm). In Fig. 5, 6 and S2 in the Supplement we show comparisons of organic carbon (OC) in particles below $2.5 \mu \mathrm{m}$ in diameter. Modeled concentrations are the sum of aSOA, bSOA and POA converted from organic aerosol mass to organic carbon assuming $\mathrm{OA} / \mathrm{OC}$ ratios of 2.0 for $\mathrm{a} / \mathrm{bSOA}$ and 1.4 for POA (comparable to findings of Aiken et al., 2008). When comparing the results from the REF run where we consider both dry and wet deposition of SVOCs we find low correlation $\left(R^{2}=0.19\right)$ and a slight low bias in the model results $(\mathrm{NMB}=-35 \%)$ when looking at the full annual cycle (Fig. 5), and better correlation $\left(R^{2}=0.31\right)$ and lower bias $(\mathrm{NMB}=-22 \%)$ when using only values of June, July, and August (Fig. S2) where 
a)
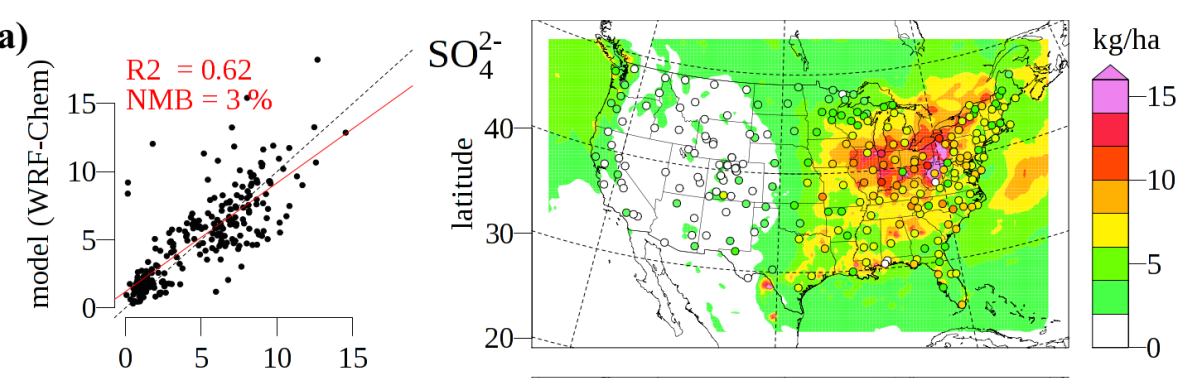

b)
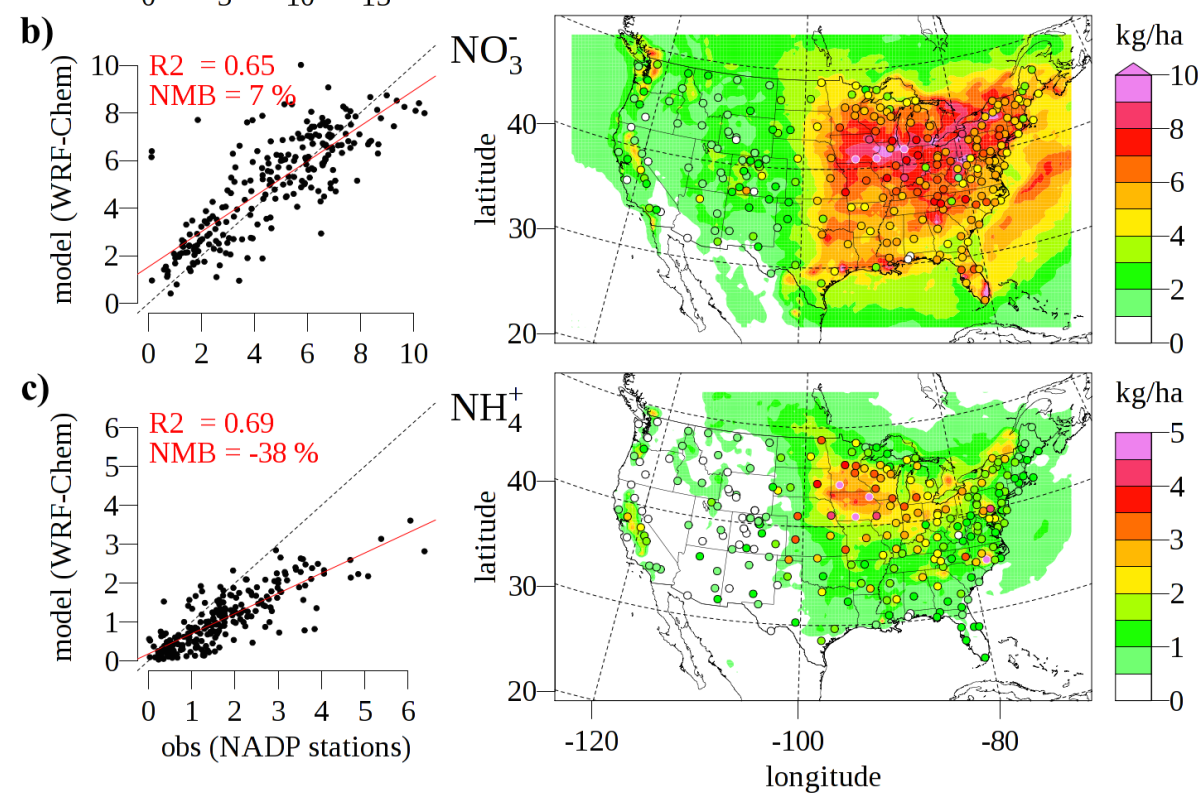

Figure 3. Year 2010 accumulated wet deposition of inorganic ions (a) $\mathrm{SO}_{4}^{2-}$, (b) $\mathrm{NO}_{3}^{-}$, and (c) $\mathrm{NH}_{4}^{+}$as measured by NADP stations (obs) and as predicted by WRF-Chem (model). The data are represented as maps (right column), with stations as circles color-coded by measured amount, and as scatterplots (left column) with $R^{2}$ as the squared Pearson correlation coefficient, and NMB as the normalized mean bias $(\mathrm{NMB}=\Sigma($ model - obs $) / \Sigma$ obs $\times 100)$.

SOA dominates OC. When analyzing the results from the simulation without SVOC removals (NODEP, bottom plot in Fig. 5), it is clear that the effect of these removals has a pronounced annual cycle, being almost negligible in winter (where POA dominates modeled OC concentrations) while reducing concentrations of secondary formed $\mathrm{OC}$ by half in summer. It is important to note that very different types of biases are observed here between the run without SVOC removals and the one where these are included: annually averaged, the OC mass predicted in the NODEP simulation would match annual averaged measured concentrations well, but there is a distinctly different evolution over the course of the year: the simulation shows a much stronger annual amplitude in OC than observed, underestimating measured values in winter and overestimating in summer. In the REF simulation with removals, the overall concentrations of OC are underestimated compared to measurements, but the month-tomonth evolution is considerably more similar to the observed evolution. We further disaggregated the analysis spatially and looked at the performance at stations at the west coast, the northeast and the southeast (Fig. 6). Our findings show that at the west coast, modeled $\mathrm{OC}$ is underestimated in all simulations, while in the Eastern US, both REF and LOWVOL results track observed OC concentrations well during July and August, but underestimate them in June. OC concentrations are overestimated in the FAST_AGING simulation, especially in the southeast.

We also compared our results to hourly measurements of organic matter $(\mathrm{OM})$ conducted within the Southeastern Aerosol Research and Characterization study (SEARCH, Hansen et al., 2012) to understand the effects of dry and wet deposition of SVOCs on the diurnal cycle of OM. Four stations in the Southeast (North Birmingham, AL-BHM; Centreville, AL-CTR; Yorkville, GAYRK; Jefferson Street, GA-JST) had measurements available (http://www.atmospheric-research.com/studies/search/ SEARCHFactSheet.pdf, for site locations and description). The resulting averaged diurnal cycles are shown in Fig. 7. We find that including wet deposition of SVOCs has no effect on the diurnal cycle of OM at these stations, possibly due to the non-local nature of this removal process: washout affects the whole column up to the cloud where the precipitation origi- 

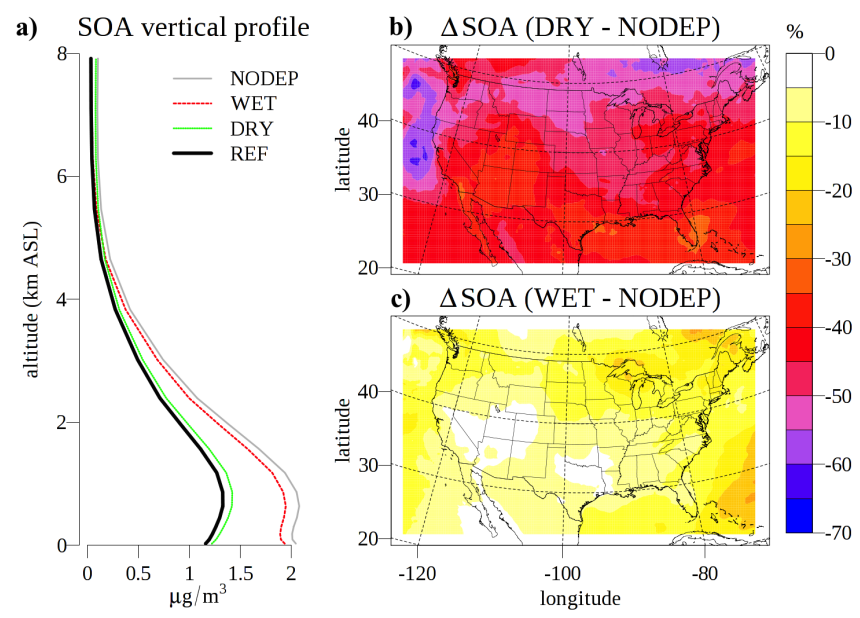

Figure 4. Effects of dry and wet deposition of SVOCs on SOA concentrations. (a) vertical profiles of SOA concentrations as yearly average over land. Changes in annual mean surface level SOA concentrations due to the consideration of (b) dry (DRY-NODEP) and (c) wet deposition (WET-NODEP) of SVOCs.

nates, hence such an event also reduces concentrations aloft, which are then advected. Dry deposition instead only acts on the lowest grid cell. Including dry deposition of SVOCs leads to a reduction in the diurnal amplitude of OM concentrations, which is in line with observations. In general, modeled diurnal amplitudes are larger than the observed ones. At all stations, with the exception of BHM, observed OM is more or less constant throughout the day. Judging based on the observations at BHM and minor variations seen at the other stations we observe that the timing of diurnal maxima and minima differ between observations and model. Modeled diurnal cycles indicate a morning minimum in OM concentrations (possibly due to the rise of the boundary layer) and a maximum in the afternoon (maximum of photochemical SOA production), whereas the observed maximum OM concentrations occur in the early morning (around 6 LT) - arguably the time with the lowest boundary layer height - and the observed minimum is during late afternoon hours (around 18 LT).

In our study we only consider "traditional" SOA formation mechanisms (pure gas-phase oxidation), but a number of additional processes have been proposed (cloud-phase formation, e.g., Lim et al., 2010; in-aerosol formation, e.g., Knote et al., 2014; evaporation of primary OA, e.g., Robinson et al., 2007; and additional formation pathways from existing precursors like isoprene, e.g., Paulot et al., 2009). Assuming that the products formed from these new sources will exhibit similar volatility/water solubility relationships than the existing compounds, the effect of SVOC removal will be similar. Including these processes would then increase concentrations shown in Fig. 5, predominantly during summer months where SOA contributes strongest to total OA, po- tentially closing the gap between measurements and model results.

\subsection{Total deposition for the different pathways}

A comparison of the monthly and yearly accumulated deposition mass through the different removal pathways is shown in Fig. 8. We find that for the total of anthropogenic and especially for biogenic SVOC $+\mathrm{SOA}$, more mass is removed as SVOCs (anthropogenics: $38.0 \%$ via dry deposition (dep.) and $24.2 \%$ through wet dep. $=62.2 \%$ total, biogenics: $54.1 \%$ via dry dep. and $21.9 \%$ through wet dep. $=76 \%$ $\%$ total) than as particles (pie charts in the right column of Fig. 8). Dry deposition is the most efficient removal process for both types of organic species. Wet deposition of SVOCs and SOA is roughly equivalent, dry deposition of particles is small $(<5 \%)$. The annual cycle of monthly accumulated deposition (left column, Fig. 8) shows a more pronounced annual variability of biogenic deposition. In winter, deposition of biogenic SVOC and SOA is negligible (due to the very low biogenic emissions), whereas deposition of anthropogenic SVOC + SOA in winter months is still about a quarter of the deposition in the summer months.

\section{Discussion of uncertainties}

The results presented above are valid for our particular model configuration. We investigated the sensitivity of these results to the model parameter space, considering uncertainties in the SOA formation mechanisms as well as in the treatment of deposition.

\subsection{Volatility of the secondary organic aerosol formed}

How susceptible SOA is to the removal of SVOCs in the gas-phase depends on the overall partitioning between the gas and particle phases. In two sensitivity studies, we change SOA volatility to investigate the impact: in LOWVOL we increase the aging rate constant into very low-volatility SOA (kOH of volatility bin with $C^{*}=1$ to the bin with $C^{*}=$ $10^{-4}$ ) by a factor of 10 , effectively hiding aged organic material from gas-phase removal. In FAST_AGING, we increase the aging rate constants between all volatility bins by a factor of 4 , reducing the time organic material is exposed to gas-phase removal during aging. Both changes result in a much less volatile distribution of mass (see also Fig. S1), which is less susceptible to gas-phase removals. The reader is referred to the Appendix for a box model study on the effects of these changes. The resulting volatility distributions are comparable to what has been observed in the atmosphere (Cappa and Jimenez, 2010), hence we deem this to be a lower bound of the effect of gas-phase removal on SOA concentrations. As expected, we find (Table 4) that the efficiency of gas-phase removal is sensitive to the volatility distribution of the organic matter. Shielding 


\section{IMPROVE Organic Carbon}
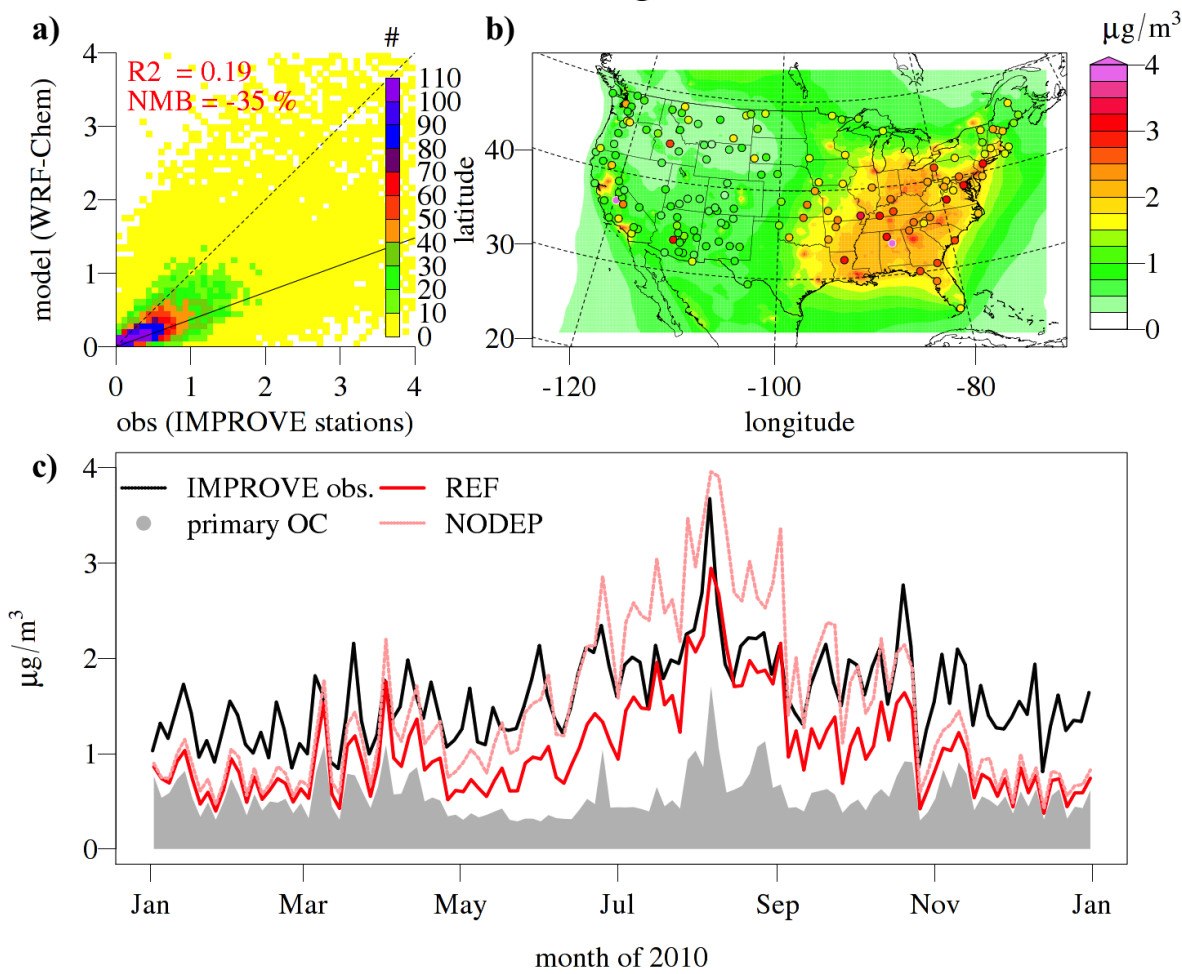

Figure 5. Evaluation of ground level total organic carbon (OC) concentrations against IMPROVE measurements. (a) density scatterplot of daily average concentrations at each IMPROVE station against modeled concentrations $\left(R^{2}\right.$ and NMB as defined in Fig. 3, again using the REF simulation). (b) annual average OC surface level concentrations (REF simulation). Filled circles represent measured concentrations. (c) time evolution of OC concentrations as average over all IMPROVE stations. Black solid line is measurement average. Grey area represents the POC (primary organic carbon) contribution to total OC (from REF simulation). Light red and red lines are NODEP and REF simulation averages of total OC respectively.

aged material from gas-phase removal (LOWVOL) lowers the average reductions of SOA concentration at the surface from $-41 /-56 \%$ (aSOA/bSOA) to $-32 /-48 \%$ vs. the NODEP case, and accelerating the aging process in general (FAST_AGING) further reduces the changes to $-23 /-39 \%$. Note that each of these changes is relative to simulations where dry and wet deposition of SVOCs has been switched off, but which employ an otherwise identical VBS scheme (LOWVOL_NODEP and FAST_AGING_NODEP respectively). In all reductions except for anthropogenic organic matter in the FAST_AGING study, more mass is removed through the gas phase than through the particle phase. When looking at the resulting concentrations and their comparison against measurements (Fig. 6) we see that FAST_AGING exhibits a time evolution almost identical to the REF run, but shifted to higher concentrations. This leads to a strong overestimation during July and August. The concentrations predicted in the LOWVOL simulation lie in between REF and FAST_AGING. It is instructive to see that in LOWVOL, the variability of concentrations over the time period investigated is reduced. This actually resembles observations better, even though there is still a low bias in the mean. This suggests that VBS schemes currently used create a volatility distribution that is too volatile compared to the real atmosphere (observed before by e.g., Grieshop et al., 2009; Hodzic et al., 2010; Cappa and Jimenez, 2010; Lee-Taylor et al., 2011), although other effects may also be important.

Interestingly, when looking at the average diurnal cycles of OM (Fig. 7), the effect of changing the volatility distribution leads to a mere shift in concentrations, but not to a change in the diurnal cycle as might have been expected.

\subsection{Water solubility of SVOCs}

Hodzic et al. (2014a) showed, based on explicit oxidation chemistry modeling, that good correlation exists between the volatility of a compound $\left(C^{*}\right)$ and its water solubility $\left(H^{*}\right)$. Still, uncertainty remains in the accuracy of these values, which is further amplified by the simplifications made in this work to apply them in a 3-D modeling context. This warrants an investigation of the sensitivity of our results to $H^{*}$. As a second motivation, the Wesely (1989) dry deposition parameterization used here is based on the analogue of a series of resistances, with Henry's law constants only 
IMPROVE Organic Carbon (JJA)
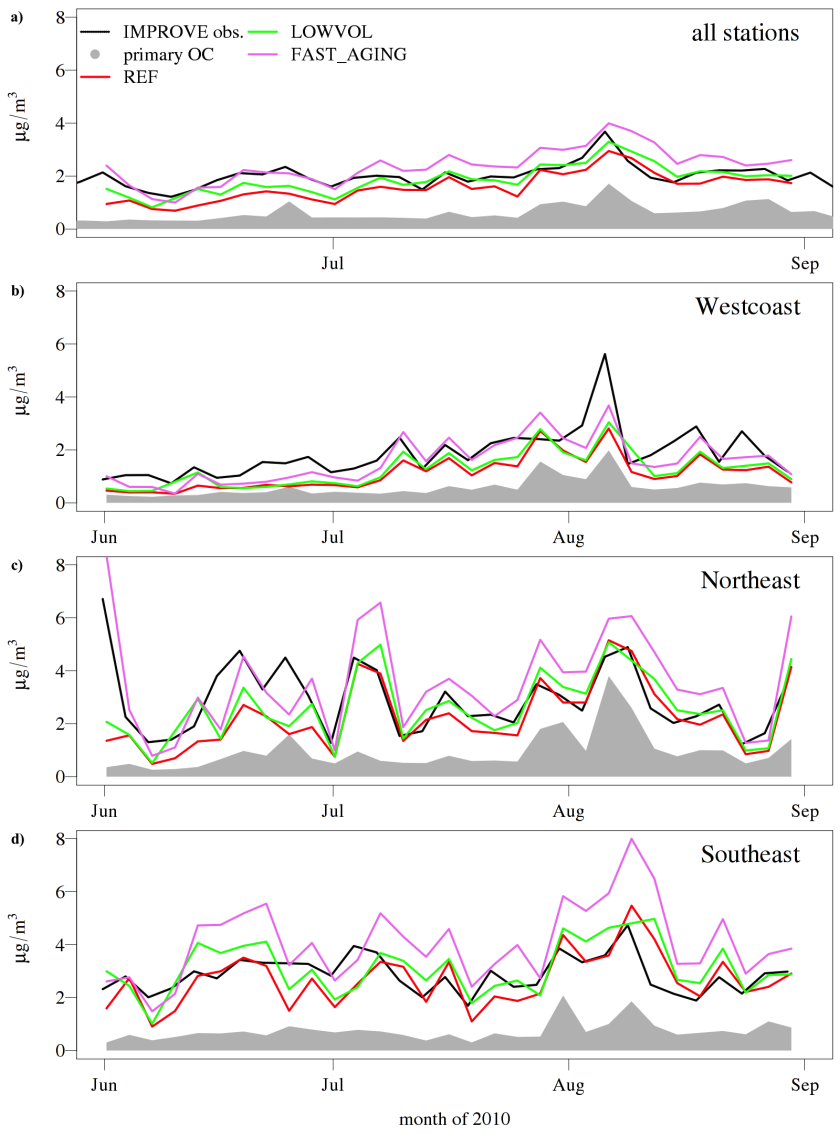

Figure 6. Time lines of ground level total organic carbon (OC) concentrations against IMPROVE measurements like in Fig. 5, but only for the summer period (June, July, and August). Green and pink lines are for LOWVOL and FAST_AGING sensitivity studies, respectively. (a) All stations. (b) West coast: California, Oregon, Washington. (c) Northeast: Connecticut, Maine, Massachusetts, New Hampshire, Vermont, New Jersey, New York, Pennsylvania, Maryland, District of Columbia, Illinois, Indiana, Michigan, and Ohio. (d) Southeast: Alabama, Florida, Kentucky, Georgia, North Carolina, South Carolina, Tennessee, West Virginia, and Virginia.

affecting the bulk surface layer resistance. Once this resistance is sufficiently low (e.g., due to very high $H^{*}$ values), the resulting dry deposition velocities are only determined by the value of the other resistances. This would imply that above a certain value of $H^{*}$, dry deposition of SVOCs should not increase anymore and no additional reduction of SOA concentrations will occur. At which values of $H^{*}$ exactly this saturation effect is observed in a realistic 3-D simulation was unknown. We hence conducted additional simulations with different values of $H^{*}$ assigned to the volatility bins: $10^{5}, 10^{8}$, and $10^{10} \mathrm{Matm}^{-1}$. In these simulations, we ignore the temperature dependence of the Henry's law constants. Additionally we included two simulations using Henry's law values derived for $\mathrm{CH}_{3} \mathrm{COOH}$
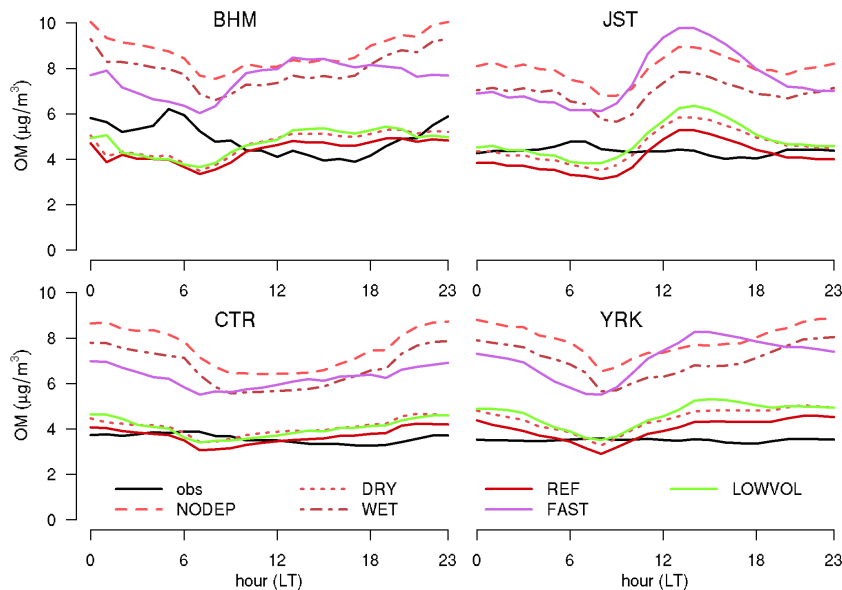

Figure 7. JJA (June, July and August) average diurnal cycles of organic matter (OM) concentrations at 4 field sites of the SEARCH network. Measurements assume an OM / OC ratio of 1.4 (Hansen et al., 2012), model results are scaled accordingly (see text).

$\left(H^{*}=4.1 \times 10^{3} \mathrm{Matm}^{-1}, \mathrm{~d}\left(\ln H^{*}\right) / \mathrm{d}(1 / T)=6300\right.$, Johnson et al. (1996)) and $\mathrm{HNO}_{3}\left(H^{*}=2.6 \times 10^{6} \mathrm{Matm}^{-1}\right.$, $\mathrm{d}\left(\ln H^{*}\right) / \mathrm{d}(1 / T)=8700$, Chameidis (1984)), commonly used in models as reference for compounds for which exact $H^{*}$ values are unknown. The resulting changes in average surface SOA concentrations and accumulated deposition (over the continental US) are shown in Fig. 9. Results from the simulation using $H^{*}$ values from explicit oxidation chemistry (REF) are included for reference. Changes in avg. SOA concentrations range from $-15 \%$ for $H^{*}=H^{*}\left(\mathrm{CH}_{3} \mathrm{COOH}\right)$ to $-60 \%$ for $H^{*}=10^{10} \mathrm{Matm}^{-1}$. A saturation effect is visible between the simulations with $H^{*}$ at $10^{8}$ and $10^{10} \mathrm{Matm}^{-1}$, where resulting SOA concentrations change by less than $5 \%$ despite changes in $H^{*}$ of 2 orders of magnitude. This suggests that the effect of deposition of SVOCs has an upper limit of $-60 \%$ reduction in avg. surface SOA concentrations for the region, time period and model setup investigated here, corresponding roughly to Henry's law constants above $10^{10} \mathrm{Matm}^{-1}$. It also shows that there is considerable variability in resulting SOA reductions within the range on $H^{*}$ values used here, urging us to find ways to better constrain these removals to accurately describe the life cycle of secondary organic aerosols. Note that these findings imply that, to be accurate, comparisons of SOA formation mechanisms implemented in 3-D models against measured concentrations will have to overestimate measured SOA concentrations by roughly $50 \%$ if SVOC deposition is ignored (REF-NODEP), by $25 \%$ if SVOC is deposited with $H^{*}=10^{5} \mathrm{Matm}^{-1}$ (REF-H_1E5), and still by $10-15 \%$ (REF-H_HNO3) if dry and wet deposition of SVOCs is considered with $H^{*}$ values of $\mathrm{HNO}_{3}$. 


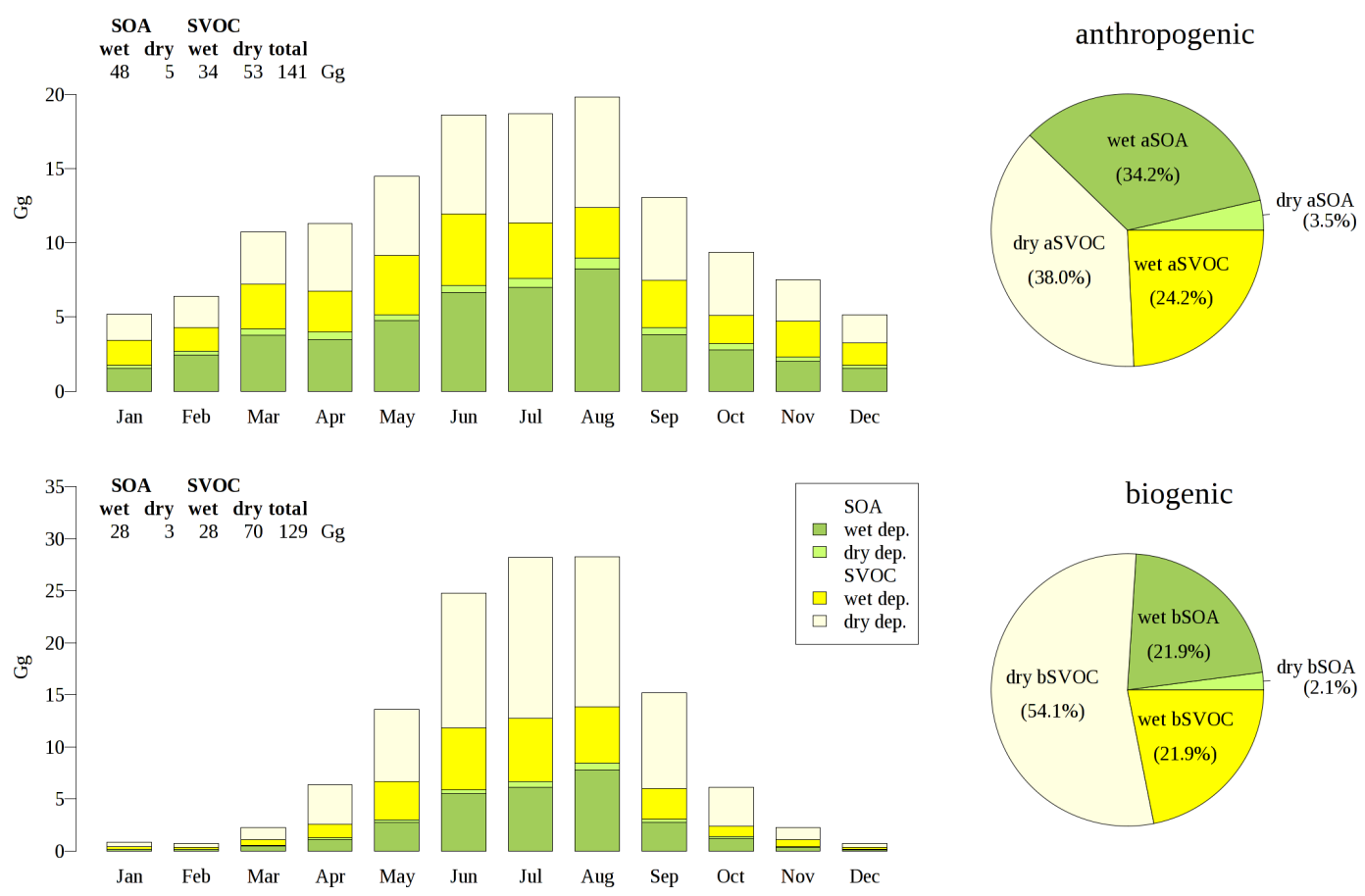

Figure 8. Monthly (left) and yearly (right) accumulated deposited mass of anthropogenic (top) and biogenic (bottom) SVOC + SOA over the continental US split into the different pathways, and shown (on the left) for simulations assuming $H^{*}$ of SVOCs according to GECKOA results (REF simulation). Table on top-left shows total annual deposited mass.

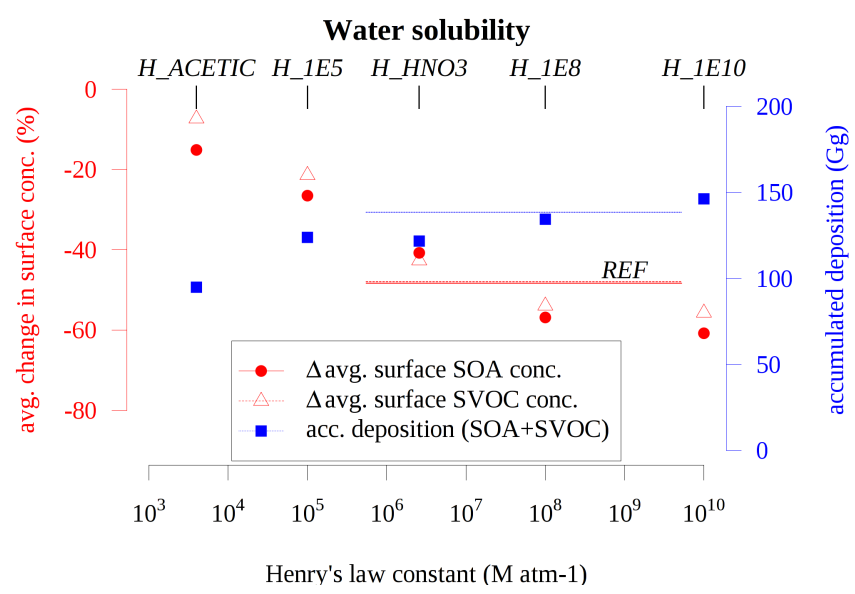

Figure 9. Sensitivity to water solubility of SVOCs $\left(H^{*}\right)$. Shown are continental US averages/totals of changes in surface level SOA (red dots)/SVOC (red triangles) concentrations and accumulated deposition of SOA + SVOCs (blue rectangles). The results of the REF simulation using the range of $H^{*}$ values derived in Hodzic et al. (2014a) are indicated as lines.

\subsection{Dry deposition scheme}

Removal of trace gases from the atmosphere through "dry deposition" is modeled based on the resistance analogy developed in Wesely (1989). While the atmospheric and laminar sublayer resistances are functions solely of the meteorolog- ical conditions and the diffusivity of the trace gas, the bulk surface resistance depends firstly on the accuracy of properties of the land surface like e.g., the vegetated fraction, leaf area index, or the type of soil present (i.e., the input data sets), and, secondly, on how these properties are translated into a bulk surface resistance value (i.e., the dry deposition scheme). Uncertainty in both the data sets as well as the scheme used introduces considerable uncertainty in the contribution of dry deposition to total removal.

Improving the description of the Earth's surface in WRFChem is a major undertaking and not part of this investigation. It was also out-of-scope of this work to replace the dry deposition scheme included. However, we conducted another sensitivity study to elucidate the magnitude of uncertainty introduced through the assumptions made in the Wesely (1989) scheme.

A possible source of error is the dependency of the bulk surface resistance calculation on the Henry's law constant even under completely dry conditions in Wesely (1989). It is sensible to scale the mesophyll and leaf cuticle resistances of vegetation by the Henry's law constant even when it is dry, as the function of the Henry's law constant there is to describe the exchange of a gas with the water within a plant cell. However, this assumption does not necessarily hold true for the lower canopy and ground resistances, which are functions of $\mathrm{H} *$ in Wesely (1989) as well. Dry deposition over structures, buildings, etc., will probably not be a function of 
the Henry's law constant under dry conditions. To consider this uncertainty and to provide a lower bound for the effect of dry deposition, we conducted a sensitivity study which we named "VEGFRA". There, we scale the dry deposition flux by the vegetated fraction in each grid cell, essentially assuming no dry deposition at all over surface types other than vegetation. Our results show (Table 4) that, even if we do not dry deposit over land surface types other than vegetation, dry deposition through the gas phase is still responsible for more than half of the total deposited mass (53 and $69 \%$ in VEGFRA instead of 59 and $74 \%$ in REF for anthropogenic and biogenic precursors, respectively), and still leads to reductions in average SOA concentrations over land of 31 and $45 \%$, respectively.

Finally, the Wesely (1989) dry deposition scheme considers the effect of chemical processing of reactive volatileorganic compounds (VOCs) within plants by adding a reactivity factor $f_{0}$ to the calculation of mesophyll and leaf cuticular resistances. An $f_{0}$ of 0 represents unreactive substances, whereas $f_{0}=1.0$ treats a species like $\mathrm{O}_{3}$ (which immediately decomposes within the plant). In our work $f_{0}$ is set to 0.0, considering SVOCs to be unreactive. Karl et al. (2010) suggested based on flux measurements that oxidized organic trace gases should be considered reactive $\left(f_{0}>0\right)$. To understand the effect of this treatment we conducted additional simulations where we set $f_{0}$ to 0.1 (F_0.1, slightly reactive) and $1.0\left(\mathrm{~F}_{-} 1.0\right.$, reactive like $\left.\mathrm{O}_{3}\right)$. We did not observe notable changes in the amount of deposited SVOCs or in SOA concentrations (not shown). This is reasoned by the fact that $H^{*}$ values from GECKO used in our study are sufficiently high so that solubility dominates the mesophyll and cuticular resistances and the additional reduction in these resistances due to reactivity is negligible.

\section{Conclusions}

We investigated the effect of considering removal of semivolatile organic compounds on secondary organic aerosols concentrations according to recent findings that suggest SVOCs are highly water soluble (Hodzic et al., 2014a). Simulations with the regional chemistry transport model WRFChem were conducted spanning the whole year 2010 over the domain of the continental US. Considering dry and wet deposition of SVOCs in the gas-phase with recently derived Henry's law constants reduces ground level SOA concentrations by $48 \%$ (aSOA) and $63 \%$ (bSOA) in the annual average over the continental US in 2010. Dry deposition is much more effective than wet deposition, reducing surface level concentrations -40 vs. $-8 \%$ for aSOA and -52 vs. $-11 \%$ for bSOA. More than half of the total mass of SVOCs + SOA (61\% for anthropogenics and $76 \%$ for biogenics) is actually deposited via the gas-phase. In a number of sensitivity studies spanning the months of June and July of 2010 we investigate the robustness of these findings by varying the volatility distribution of the organic matter, the Henry's law constants used, and key parameters of the dry deposition scheme. We find that the efficiency of these removals is sensitive to the volatility of the mixture, reducing the resulting reductions in surface level SOA concentrations from $-48 \%$ (avg. of changes in aSOA and bSOA) in the standard simulation (REF) to $-40 \%$ when protecting aged SOA from gas-phase removal (LOWVOL), and to $-31 \%$ when accelerating the aging process in general (FAST_AGING). SOA is sensitive to the removal of SVOCs in the gas phase through dry and wet deposition for the whole range of $H^{*}$ values investigated, with average reductions in surface SOA concentrations of $-25 \%$ when assuming $H^{*}=10^{5} \mathrm{M} \mathrm{atm}^{-1}$, scaling up to $-60 \%$ for $H^{*}=10^{10} \mathrm{Matm}^{-1}$. A saturation effect is clearly visible for $H^{*} \geq 10^{8} \mathrm{Matm}^{-1}$, suggesting that the upper bound of these processes on SOA concentrations is reached. These results are also sensitive to assumptions made in the dry deposition scheme, reducing the effect of considering dry deposition of SVOCs on changes in average surface SOA concentrations to $-31 \% /-45 \%$ when dry deposition is only considered over vegetated areas. Considering reactivity of SVOCs in the dry deposition calculation over vegetation as suggested by Karl et al. (2010) had no observable effect as the high values of water solubility calculated by GECKO dominate the calculation of the vegetation-related resistances.

Our findings have important implications for the aerosol modeling community, as they show that considering dry as well as wet deposition of SVOCs in the gas phase is an essential part of accurately modeling SOA. Any evaluation of regional SOA modeling against observed concentrations of particulate organic matter is biased high about $50 \%$ if SVOC removal is neglected completely, about $25 \%$ if SVOC removal is considered with a Henry's law constant $H^{*}=10^{5} \mathrm{Matm}^{-1}$, and still $10 \%$ if the water solubility of $\mathrm{HNO}_{3}$ is used. We also showed that the removal processes are still sensitive to the value of the Henry's law constant $H^{*}$ used up to around $10^{8} \mathrm{Matm}^{-1}$. Finally, considerable uncertainty remains in the description of dry deposition. For all the uncertainties investigated we find that, while the actual resulting numbers vary, dry deposition of SVOCs remains an important pathway of SOA removal.

Including these processes suggests further that there is room for additional pathways (e.g., in-cloud, in-aerosol production) and precursors (evaporating POA, glyoxal) of SOA in order to close the gap with observations. We evaluated the modeling system against measurements of precipitation and wet deposition of inorganic ions, which lends confidence that the underlying wet removal process is accurately captured. However, we are currently not able to observationally constrain the organic carbon budget until a network of long-term, routine measurements of dry and wet deposition of organic matter is established. 


\section{Appendix A: Box model simulations}

How efficient the removal of gas-phase SVOCs is in decreasing SOA concentrations depends directly on the amount of SVOCs created by the oxidation of precursors (vs. the production of very low volatility compounds that partition predominantly in the particle phase), and the time it takes for subsequent chemistry to decrease the compound's volatility enough so that it remains in the particle phase. In VBS terminology it is a function of the yields distribution and the "aging" rate constant, $k_{\text {aging. To investigate }}$ these sensitivities, we simulate chamber experiments in a box model, employing VBS-type parameterizations with different assumptions. In Figs. A1 and A2, we show the results of the oxidation of $1 \mathrm{ppbv} \alpha$-pinene $(\mathrm{kOH}(\alpha$-pinene $)=$ $\left.5.2 \times 10^{-11} \mathrm{~cm}^{3} \mathrm{molec}^{-1} \mathrm{~s}^{-1}\right)$ and toluene $(\mathrm{kOH}$ (toluene $)=$ $\left.1.7 \times 10^{-12} \times \exp (352 / T) \mathrm{cm}^{3} \mathrm{molec}^{-1} \mathrm{~s}^{-1}\right)$, assuming constant $\mathrm{OH}$ of $2.0 \times 10^{6} \mathrm{moleccc}^{-1}$, and subsequent formation of SOA using the yields of Lane et al. (2008b). Four different VBS parameterizations are presented: as described in Lane et al. (2008b) (LANE), as described as base case in this work (NODEP), a low-volatility sensitivity study used in this work that "protects" aged material by moving into an "inert" volatility bin (LOWVOL), and a sensitivity study where the overall aging of SVOCs is accelerated (FAST_AGING). In all parameterizations we assume that chemistry of later generation compounds further reduces their volatility, which is approximated by reducing SVOC volatility by a decade ( 1 bin) with an "aging" rate constant of kaging $=1 \times 10^{-11} \mathrm{~cm}^{3} \mathrm{molec}^{-1} \mathrm{~s}^{-1}$. In the LOWVOL sensitivity study, kaging from the bin with $C^{*}=1.0$ to $C^{*}=$ $1.0 \times 10^{-4}$ is increased to $1 \times 10^{-10} \mathrm{~cm}^{3} \mathrm{molec}^{-1} \mathrm{~s}^{-1}$. In FAST_AGING, the aging rate constants for all bins are increased to $4 \times 10^{-11} \mathrm{~cm}^{3} \mathrm{molec}^{-1} \mathrm{~s}^{-1}$. A first-order loss (efolding lifetime of 1 day) is applied to the vapor phase in all bins to simulate SVOC deposition. Temperature varies as sine function around $298 \mathrm{~K}$ with a $10 \mathrm{~K}$ amplitude and a wave-length of $24 \mathrm{~h}$.

SOA formation from $\alpha$-pinene peaks in the first hours of the simulation due to faster reaction with $\mathrm{OH}$ (Fig. A1, third row) and higher yields. After $\alpha$-pinene is depleted, toluene provides additional condensable vapors mass almost throughout the $120 \mathrm{~h}$ simulated. Clearly visible from the volatility distributions after $24 \mathrm{~h}$ (Fig. A1, top row) is that in REF, LOWVOL, and especially in FAST_AGING, a substantial amount of mass is shifted into the particle phase due to aging into the "inert" bin at $C^{*}=1 \times 10^{-4}$ compared to LANE. We compare these results to the thermodenuder experiments of Cappa and Jimenez (2010) where they find that the semi-volatile fraction of oxygenated organic aerosol (SVOOA, Fig. 5f in Cappa and Jimenez, 2010) has 2/3 of the total mass (gas+particle) of compounds with $C^{*} \leq 2$ in the particle phase. It is evident that the three different parameterizations exhibit very different sensitivities to changes in temperature. LANE uses a relatively low enthalpy of vapor- ization $(\mathrm{dH})$ of $30 \mathrm{~kJ} \mathrm{~mol}^{-1}$, and consequently the total SOA mass (Fig. A1, second row) does not vary strongly. In the REF, LOWVOL and FAST_AGING parameterizations the higher $\mathrm{dH}$ of $>100 \mathrm{~kJ} \mathrm{~mol}^{-1}$ (parameterization of Epstein et al., 2009) are used, and these simulations initially react much stronger to changes in temperature. It is notable, however, that in the LOWVOL and FAST_AGING cases, temperature sensitivity quickly decreases and the result is almost completely insensitive to temperature after $72 \mathrm{~h}$. This is obviously the result of moving mass more quickly into the "inert" bin (Fig. A2).

As the four parameterizations exhibit very different volatility distributions, application of a loss process to simulate SVOC deposition leads to very different total mass concentrations (Fig. A1, second row) and volatility distributions after $120 \mathrm{~h}$ (Fig. A2). While LANE only has $0.5 \mu \mathrm{g} \mathrm{m}^{-3}$ of SOA left (down from $>1 \mu \mathrm{g} \mathrm{m}^{-3}$ after $42 \mathrm{~h}$ ), REF ends up with $2 \mu \mathrm{g} \mathrm{m}^{-3}$, LOWVOL with almost $3 \mu \mathrm{g} \mathrm{m}^{-3}$, and FAST_AGING with $5 \mu \mathrm{g} \mathrm{m}^{-3}$ of SOA after $120 \mathrm{~h}$. The inert bin protects SOA mass from being depleted via equilibration with the gas phase and subsequent removal through deposition. This effect is even stronger in the LOWVOL and FAST_AGING cases, as the overall exposure time (from initial formation to ending up in the inert bin) is shorter. 
LANE

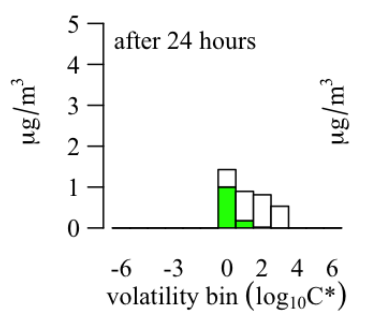

REF

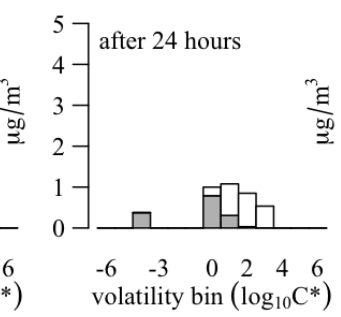

LOWVOL

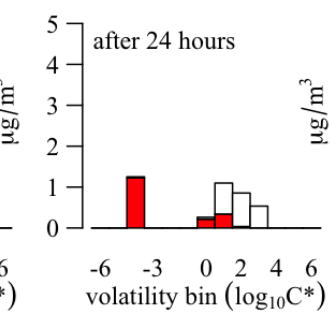

FAST_AGING

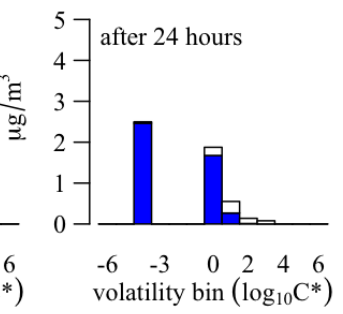

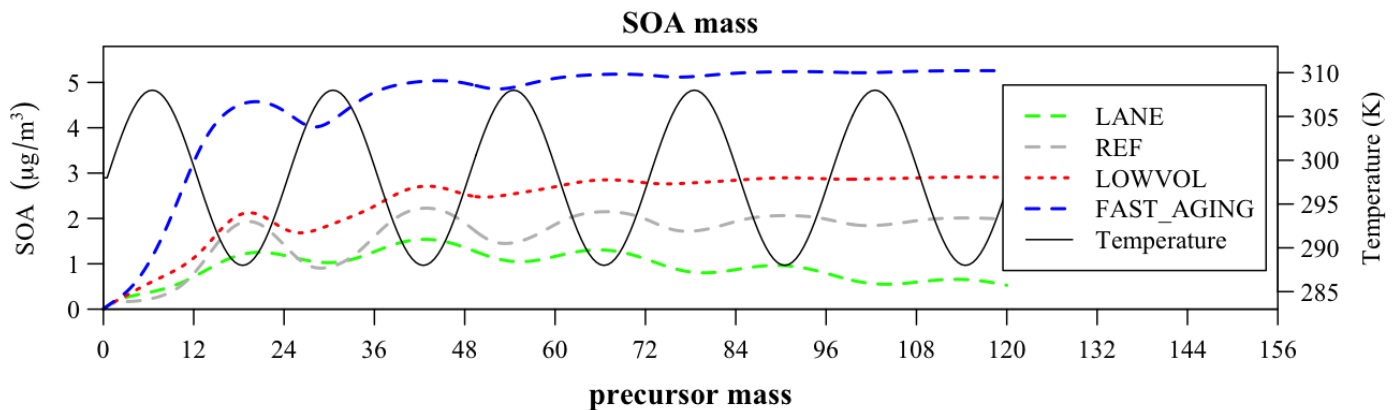

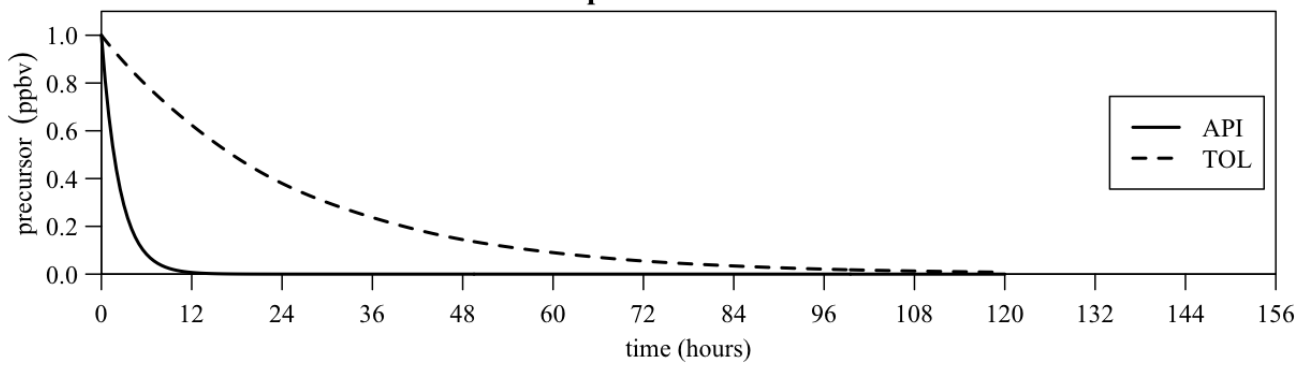

Figure A1. Box-model simulations of the oxidation of $1 \mathrm{ppbv} \alpha$-pinene and toluene. Top row: distribution of particulate (colored) and vapor mass (white) in the different volatility bins after $24 \mathrm{~h}$. Second row: total particle mass of SOA formed, as well as temperature. Third row: time evolution of precursor concentration. 

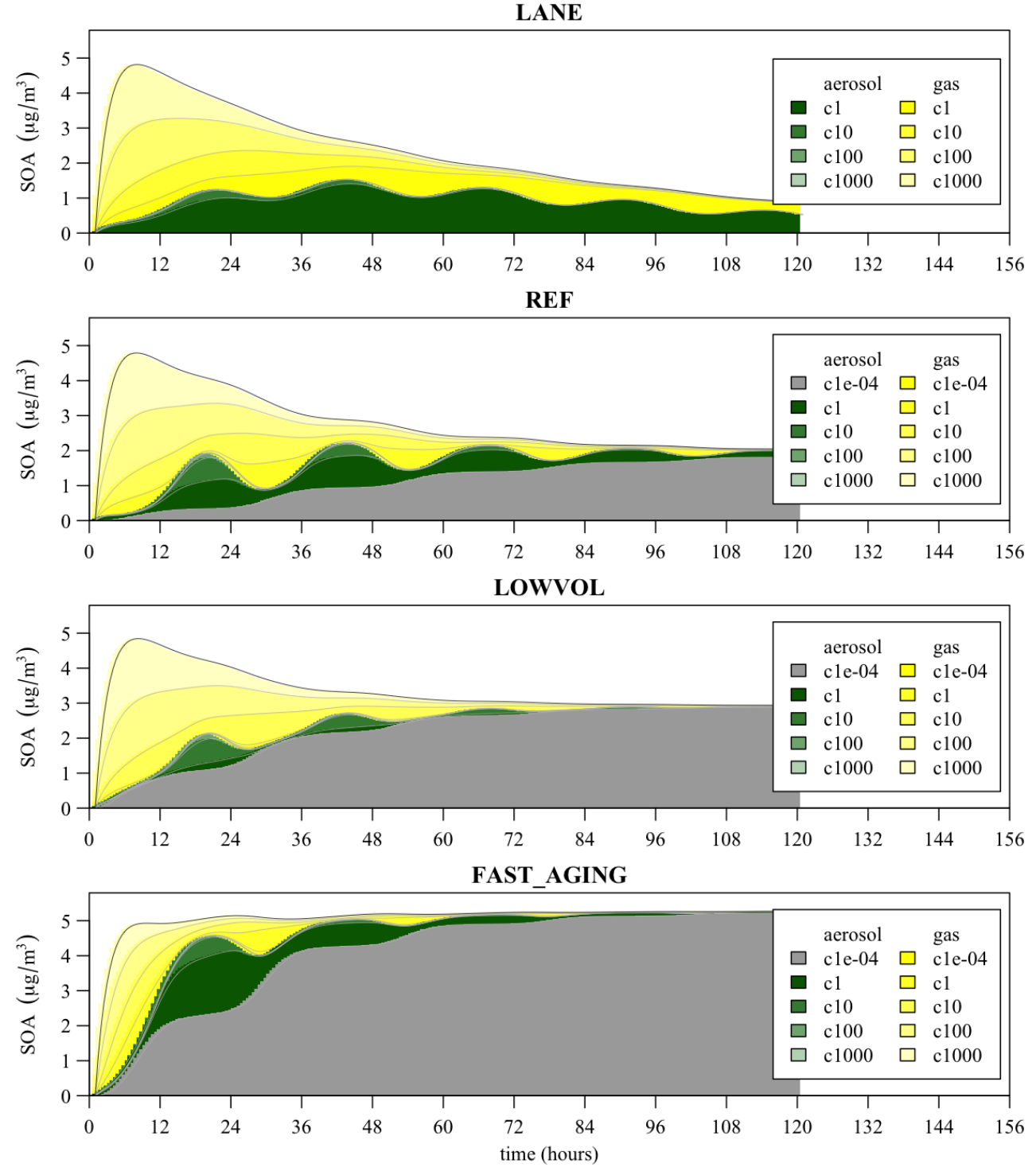

Figure A2. Evolution of mass distribution in the particle and vapor phases in the box model simulations for the different parameterizations. 


\section{The Supplement related to this article is available online at doi:10.5194/acp-15-1-2015-supplement.}

Acknowledgements. Sascha Madronich is thanked for fruitful discussions. We used data from the NADP network (National Atmospheric Deposition Program (NRSP-3) 2014. NADP Program Office, Illinois State Water Survey, 2204 Griffith, Champaign, IL 61820) and thank NADP for providing these. This research was supported by the National Center for Atmospheric Research, which is operated by the University Corporation for Atmospheric Research on behalf of the National Science Foundation, and by the DOE grant DE-SC0006711. Any opinions, findings and conclusions or recommendations expressed in the publication are those of the author(s) and do not necessarily reflect the views of the National Science Foundation. JLJ was supported by DOE (BER/ASR) DE-SC0006035, CARB 11-305, and NOAA NA13OAR4310063.

Edited by: A. Carlton

\section{References}

Ahmadov, R., McKeen, S., Robinson, A., Bahreini, R., Middlebrook, A., Gouw, J. D., Meagher, J., Hsie, E.-Y., Edgerton, E., Shaw, S., and Trainer, M.: A volatility basis set model for summertime secondary organic aerosols over the eastern United States in 2006, J. Geophys. Res.-Atmos., 117, D06301, doi:10.1029/2011JD016831, 2012.

Aiken, A. C., DeCarlo, P. F., Kroll, J. H., Worsnop, D. R., Huffman, J. A., Docherty, K. S., Ulbrich, I. M., Mohr, C., Kimmel, J. R., Sueper, D., Sun, Y., Zhang, Q., Trimborn, A., Northway, M., Ziemann, P. J., Canagaratna, M. R., Onasch, T. B., Alfarra, M. R., Prevot, A., Dommen, J., Duplissy, J., Metzger, A., Baltensperger, U., and Jimenez, J. L.: O / C and OM / OC ratios of primary, secondary, and ambient organic aerosols with high-resolution time-of-flight aerosol mass spectrometry, Environ. Sci. Technol., 42, 4478-4485, 2008.

Alapaty, K., Mathur, R., Pleim, J., Hogrefe, C., Rao, S. T., Ramaswamy, V., Galmarini, S., Schaap, M., Makar, P., Vautard, R., Baklanov, A., Kallos, G., Vogel, B., and Sokhi, R., New directions: Understanding interactions of air quality and climate change at regional scales, Atmos. Environ., 49, 419-421, 2012.

Athanasopoulou, E., Vogel, H., Vogel, B., Tsimpidi, A. P., Pandis, S. N., Knote, C., and Fountoukis, C.: Modeling the meteorological and chemical effects of secondary organic aerosols during an EUCAARI campaign, Atmos. Chem. Phys., 13, 625-645, doi:10.5194/acp-13-625-2013, 2013.

Aumont, B., Szopa, S., and Madronich, S.: Modelling the evolution of organic carbon during its gas-phase tropospheric oxidation: development of an explicit model based on a self generating approach, Atmos. Chem. Phys., 5, 2497-2517, doi:10.5194/acp-52497-2005, 2005.

Bash, J. O., Cooter, E. J., Dennis, R. L., Walker, J. T., and Pleim, J. E.: Evaluation of a regional air-quality model with bidirectional $\mathrm{NH}_{3}$ exchange coupled to an agroecosystem model, Biogeosciences, 10, 1635-1645, doi:10.5194/bg-10-1635-2013, 2013.
Bessagnet, B., Seigneur, C., and Menut, L.: Impact of dry deposition of semi-volatile organic compounds on secondary organic aerosols, Atmos. Environ., 44, 1781-1787, 2010.

Cappa, C. D. and Jimenez, J. L.: Quantitative estimates of the volatility of ambient organic aerosol, Atmos. Chem. Phys., 10, 5409-5424, doi:10.5194/acp-10-5409-2010, 2010.

Chameidis, W. L.: The photochemistry of a remote marine stratiform cloud, J. Geophys. Res., 89, 4739-4755, doi:10.1029/JD089iD03p04739, 1984.

Chapman, E. G., Gustafson Jr., W. I., Easter, R. C., Barnard, J. C., Ghan, S. J., Pekour, M. S., and Fast, J. D.: Coupling aerosolcloud-radiative processes in the WRF-Chem model: Investigating the radiative impact of elevated point sources, Atmos. Chem. Phys., 9, 945-964, doi:10.5194/acp-9-945-2009, 2009.

Computational and Information Systems Laboratory: Yellowstone: IBM iDataPlex System (NCAR Community Computing), available at: http://n2t.net/ark:/85065/d7wd3xhc (last access: April 2014), National Center for Atmospheric Research, Boulder, CO, 2012.

Easter, R. C., Ghan, S. J., Zhang, Y., Saylor, R. D., Chapman, E. G., Laulainen, N. S., Abdul-Razzak, H., Leung, L. R., Bian, X., and Zaveri, R. A.: MIRAGE: model description and evaluation of aerosols and trace gases, J. Geophys. Res.-Atmos., 109, D20210, doi:10.1029/2004JD004571, 2004.

Emmons, L. K., Walters, S., Hess, P. G., Lamarque, J.-F., Pfister, G. G., Fillmore, D., Granier, C., Guenther, A., Kinnison, D., Laepple, T., Orlando, J., Tie, X., Tyndall, G., Wiedinmyer, C., Baughcum, S. L., and Kloster, S.: Description and evaluation of the Model for Ozone and Related chemical Tracers, version 4 (MOZART-4), Geosci. Model Dev., 3, 43-67, doi:10.5194/gmd3-43-2010, 2010.

Epstein, S. A., Riipinen, I., and Donahue, N. M.: A semiempirical correlation between enthalpy of vaporization and saturation concentration for organic aerosol, Environ. Sci. Technol., 44, 743748, 2009.

Grell, G. A. and Dévényi, D.: A generalized approach to parameterizing convection combining ensemble and data assimilation techniques, Geophys. Res. Lett., 29, 38-1-38-4, doi:10.1029/2002GL015311, 2002.

Grell, G., Peckham, S., Schmitz, R., McKeen, S., Frost, G., Skamarock, W., and Eder, B.: Fully coupled online chemistry within the WRF model, Atmos. Environ., 39, 6957-6975, 2005.

Grieshop, A. P., Logue, J. M., Donahue, N. M., and Robinson, A. L.: Laboratory investigation of photochemical oxidation of organic aerosol from wood fires 1: measurement and simulation of organic aerosol evolution, Atmos. Chem. Phys., 9, 1263-1277, doi:10.5194/acp-9-1263-2009, 2009.

Hansen, D. A., Edgerton, E. S., Hartsell, B. E., Jansen, J. J., Kandasamy, N., Hidy, G. M., and Blanchard, C. L.: The Southeastern Aerosol Research and Characterization Study: Part 1 - Overview, Journal of the Air \& Waste Management Association, 53, 1460 1471, 2012.

Hodzic, A., Jimenez, J. L., Madronich, S., Canagaratna, M. R., DeCarlo, P. F., Kleinman, L., and Fast, J.: Modeling organic aerosols in a megacity: potential contribution of semi-volatile and intermediate volatility primary organic compounds to secondary organic aerosol formation, Atmos. Chem. Phys., 10, 5491-5514, doi:10.5194/acp-10-5491-2010, 2010. 
Hodzic, A., Madronich, S., Aumont, B., Lee-Taylor, J., Karl, T., Camredon, M., and Mouchel-Vallon, C.: Limited influence of dry deposition of semivolatile organic vapors on secondary organic aerosol formation in the urban plume, Geophys. Res. Lett., 40, 3302-3307, 2013.

Hodzic, A., Aumont, B., Knote, C., Lee-Taylor, J., Madronich, S., and Tyndall, G.: Volatility Dependence of Henry's Law Constants Of Condensable Organics: Application to Estimate Depositional Loss of Secondary Organic Aerosols, Geophys. Res. Lett., 41, 4795-4804, doi:10.1002/2014GL060649, doi:10.1002/2014GL060649, 2014a.

Hodzic, A., Gochis D., Cui, Y., et al.: Meteorological conditions, emissions and transport of anthropogenic pollutants over the Central Rocky Mountains during the 2011 BEACHONRoMBAS field study, in preparation, 2014b.

Johnson, B. J., Betterton, E. A., and Craig, D.: Henry's law coefficients of formic and acetic acids, J. Atmos. Chem., 24, 113-119, 1996.

Jimenez, J., Canagaratna, M., Donahue, N., Prevot, A., Zhang, Q., Kroll, J., DeCarlo, P., Allan, J., Coe, H., Ng, N., Aiken, A. C., Docherty, K. S., Ulbrich, I. M., Grieshop, A. P., Robinson, A. L., Duplissy, J., Smith, J. D., Wilson, K. R., Lanz, V. A., Hueglin, C., Sun, Y., Tian, J., Laaksonen, A., Raatikainen, T., Rautiainen, J., Vaattovaara, P., Ehn, M., Kulmala, M., Tomlinson, J. M., Collins, D. R., Cubison, M. J., Dunlea, E., Huffman, J. A., Onasch, T. B., Alfarra, M. R., Williams, P. I., Bower, K., Kondo, Y., Schneider, J., Drewnick, F., Borrmann, S., Weimer, S., Demerjian, K., Salcedo, D., Cottrell, L., Griffin, R. J., Takami, A., Miyoshi, T., Hatakeyama, S., Shimono, A., Sun, Y., Zhang, Y. M., Dzepina, K., Kimmel, J. R., Sueper, D., Jayne, J. T., Herndon, S. C., Trimborn, A., Williams, L., Wood, E. C., Middlebrook, A. M., Kolb, C. E., Baltensperger, U., and Worsnop, D. R.: Evolution of organic aerosols in the atmosphere, Science, 326, 1525-1529, 2009.

Karl, T., Harley, P., Emmons, L., Thornton, B., Guenther, A., Basu, C., Turnipseed, A., and Jardine, K.: Efficient atmospheric cleansing of oxidized organic trace gases by vegetation, Science, 330, 816-819, 2010.

Knote, C., Hodzic, A., Jimenez, J. L., Volkamer, R., Orlando, J. J., Baidar, S., Brioude, J., Fast, J., Gentner, D. R., Goldstein, A. H., Hayes, P. L., Knighton, W. B., Oetjen, H., Setyan, A., Stark, H., Thalman, R., Tyndall, G., Washenfelder, R., Waxman, E., and Zhang, Q.: Simulation of semi-explicit mechanisms of SOA formation from glyoxal in aerosol in a 3-D model, Atmos. Chem. Phys., 14, 6213-6239, doi:10.5194/acp-14-6213-2014, 2014.

Lamarque, J.-F., Emmons, L. K., Hess, P. G., Kinnison, D. E., Tilmes, S., Vitt, F., Heald, C. L., Holland, E. A., Lauritzen, P. H., Neu, J., Orlando, J. J., Rasch, P. J., and Tyndall, G. K.: CAM-chem: description and evaluation of interactive atmospheric chemistry in the Community Earth System Model, Geosci. Model Dev., 5, 369-411, doi:10.5194/gmd-5-369-2012, 2012.

Lane, T. E., Donahue, N. M., and Pandis, S. N.: Effect of $\mathrm{NO}_{\mathrm{x}}$ on secondary organic aerosol concentrations, Environ. Sci. Technol., 42, 6022-6027, 2008a.

Lane, T. E., Donahue, N. M., and Pandis, S. N.: Simulating secondary organic aerosol formation using the volatility basis-set approach in a chemical transport model, Atmos. Environ., 42, 7439-7451, 2008b.
Lee-Taylor, J., Madronich, S., Aumont, B., Baker, A., Camredon, M., Hodzic, A., Tyndall, G. S., Apel, E., and Zaveri, R. A.: Explicit modeling of organic chemistry and secondary organic aerosol partitioning for Mexico City and its outflow plume, Atmos. Chem. Phys., 11, 13219-13241, doi:10.5194/acp-1113219-2011, 2011.

Lim, Y. B., Tan, Y., Perri, M. J., Seitzinger, S. P., and Turpin, B. J.: Aqueous chemistry and its role in secondary organic aerosol (SOA) formation, Atmos. Chem. Phys., 10, 1052110539, doi:10.5194/acp-10-10521-2010, 2010.

Murphy, B. N. and Pandis, S. N.: Simulating the formation of semivolatile primary and secondary organic aerosol in a regional chemical transport model, Environ. Sci. Technol., 43, 47224728, 2009.

Murphy, D., Cziczo, D., Froyd, K., Hudson, P., Matthew, B., Middlebrook, A., Peltier, R. E., Sullivan, A., Thomson, D., and Weber, R.: Single-particle mass spectrometry of tropospheric aerosol particles, J. Geophys. Res.-Atmos., 111, D23S32, doi:10.1029/2006JD007340, 2006.

National Centers for Environmental Prediction/National Weather Service/NOAA/US Department of Commerce: NCEP FNL Operational Model Global Tropospheric Analyses, continuing from July 1999, Research Data Archive at the National Center for Atmospheric Research, Computational and Information Systems Laboratory, Boulder, Colo (updated daily), doi:10.5065/D6M043C6, 2000.

Nemitz, E., Milford, C., and Sutton, M. A.: A two-layer canopy compensation point model for describing bi-directional biosphere-atmosphere exchange of ammonia, Q. J. Roy. Meteor. Soc., 127, 815-833, 2001.

Neu, J. L. and Prather, M. J.: Toward a more physical representation of precipitation scavenging in global chemistry models: cloud overlap and ice physics and their impact on tropospheric ozone, Atmos. Chem. Phys., 12, 3289-3310, doi:10.5194/acp-12-32892012, 2012.

Odum, J. R., Hoffmann, T., Bowman, F., Collins, D., Flagan, R. C., and Seinfeld, J. H.: Gas/particle partitioning and secondary organic aerosol yields, Environ. Sci. Technol., 30, 2580-2585, 1996.

Pankow, J. F.: An absorption model of gas/particle partitioning of organic compounds in the atmosphere, Atmos. Environ., 28, 185-188, 1994.

Paulot, F., Crounse, J. D., Kjaergaard, H. G., Kürten, A., Clair, J. M. S., Seinfeld, J. H., and Wennberg, P. O.: Unexpected epoxide formation in the gas-phase photooxidation of isoprene, Science, 325, 730-733, 2009.

Pouliot, G., Denier can der Gon, H., Kuenen, J., Makar, P., Zhang, J., and Moran, M.: Analysis of the Emission Inventories and Model-Ready Emission Datasets of Europe and North America for Phase 2 of the AQMEII Project, Atmos. Environ., doi:10.1016/j.atmosenv.2014.10.061, accepted, 2014.

Pye, H. O. T. and Seinfeld, J. H.: A global perspective on aerosol from low-volatility organic compounds, Atmos. Chem. Phys., 10, 4377-4401, doi:10.5194/acp-10-4377-2010, 2010.

Rao, S. T., Galmarini, S., and Puckett, K.: Air Quality Model Evaluation International Initiative (AQMEII): advancing the state of the science in regional photochemical modeling and its applications, B. Am. Meteorol. Soc., 92, 23-30, 2011. 
Raventos-Duran, T., Camredon, M., Valorso, R., Mouchel-Vallon, C., and Aumont, B.: Structure-activity relationships to estimate the effective Henry's law constants of organics of atmospheric interest, Atmos. Chem. Phys., 10, 7643-7654, doi:10.5194/acp10-7643-2010, 2010.

Robinson, A. L., Donahue, N. M., Shrivastava, M. K., Weitkamp, E. A., Sage, A. M., Grieshop, A. P., Lane, T. E., Pierce, J. R., and Pandis, S. N.: Rethinking organic aerosols: semivolatile emissions and photochemical aging, Science, 315, 1259-1262, 2007.

Shrivastava, M., Fast, J., Easter, R., Gustafson Jr., W. I., Zaveri, R. A., Jimenez, J. L., Saide, P., and Hodzic, A.: Modeling organic aerosols in a megacity: comparison of simple and complex representations of the volatility basis set approach, Atmos. Chem. Phys., 11, 6639-6662, doi:10.5194/acp-11-6639-2011, 2011.

Stein, O., Flemming, J., Inness, A., Kaiser, J. W., and Schultz, M. G.: Global reactive gases forecasts and reanalysis in the MACC project, J. Int. Environ. Sci., 9, 57-70, 2012.

Tsigaridis, K., Daskalakis, N., Kanakidou, M., Adams, P. J., Artaxo, P., Bahadur, R., Balkanski, Y., Bauer, S. E., Bellouin, N., Benedetti, A., Bergman, T., Berntsen, T. K., Beukes, J. P., Bian, H., Carslaw, K. S., Chin, M., Curci, G., Diehl, T., Easter, R. C., Ghan, S. J., Gong, S. L., Hodzic, A., Hoyle, C. R., Iversen, T., Jathar, S., Jimenez, J. L., Kaiser, J. W., Kirkevåg, A., Koch, D., Kokkola, H., Lee, Y. H, Lin, G., Liu, X., Luo, G., Ma, X., Mann, G. W., Mihalopoulos, N., Morcrette, J.-J., Müller, J.-F., Myhre, G., Myriokefalitakis, S., Ng, N. L., O’Donnell, D., Penner, J. E., Pozzoli, L., Pringle, K. J., Russell, L. M., Schulz, M., Sciare, J., Seland, Ø., Shindell, D. T., Sillman, S., Skeie, R. B., Spracklen, D., Stavrakou, T., Steenrod, S. D., Takemura, T., Tiitta, P., Tilmes, S., Tost, H., van Noije, T., van Zyl, P. G., von Salzen, K., Yu, F., Wang, Z., Wang, Z., Zaveri, R. A., Zhang, H., Zhang, K., Zhang, Q., and Zhang, X.: The AeroCom evaluation and intercomparison of organic aerosol in global models, Atmos. Chem. Phys., 14, 10845-10895, doi:10.5194/acp-1410845-2014, 2014.
Wesely, M.: Parameterization of surface resistances to gaseous dry deposition in regional-scale numerical models, Atmos. Environ., 23, 1293-1304, 1989.

Zaveri, R. A., Easter, R. C., Fast, J. D., and Peters, L. K.: Model for simulating aerosol interactions and chemistry (MOSAIC), J. Geophys. Res.-Atmos., 113, D13204, doi:10.1029/2007JD008782, 2008. 